Journal of Marine Systems

August 2015, Volume 148, Pages 70-85

http://dx.doi.org/10.1016/i.jmarsys.2015.02.001

http://archimer.ifremer.fr/doc/00252/36303/

(c) 2015 Elsevier B.V. All rights reserved.

\title{
The exceptional surface turbidity of the North-West European shelf seas during the stormy 2013-2014 winter: consequences for the initiation of the phytoplankton blooms?
}

\author{
Gohin Francis $^{1, *}$, Bryere Philippe ${ }^{2}$, Griffiths Joshua ${ }^{1,3}$ \\ ${ }^{1}$ IFREMER, IFREMER/DYNECO/PELAGOS, Centre Ifremer de Brest, CS10070, 29280 Plouzané, \\ Brittany, France \\ ${ }^{2}$ ACRI-HE, 40 Quai de la douane, 29200 Brest, Brittany, France \\ ${ }^{3}$ School of Ocean Sciences, Bangor University, Menai Bridge, Anglesey, LL595AB, United Kingdom \\ * Corresponding author : Francis Gohin, Tel.: + 332982243 15; fax: + 33298224548 ; \\ email address : Francis.Gohin@ifremer.fr
}

\begin{abstract}
:
A succession of storms during the winter 2013-2014 enhanced the resuspension of sediments in the surface waters of the North-West European shelf seas. The effects of waves on satellite-derived nonalgal SPM (Suspended Particulate Matters) are discussed for the January 2008-March 2014 period. A simple statistical model relating locally SPM to tidal intensity and waves help us analyse the main characteristics of the winter 2013-2014. The exceptional run of storms observed in this stormy and rainy winter has resulted in the highest SPM concentration in the Celtic Sea and the Bay of Biscay ever observed by remote-sensing during the 1998-2014 period. Despite the lower clarity of the surface waters over a large part of the continental shelf during the first days of March 2014, blooms occurred early off the coast of Southern Brittany (Bay of Biscay) and later in April, as usual, in the Celtic Sea. Off the coast of southern Brittany, a region of freshwater influence, the lower clarity of the waters was counterbalanced by stronger haline stratification, due to high river discharges, enabling the initiation of blooms in late winter when the solar irradiance is sufficient; which was the case in March 2014 with 7 sunny days in a row just after the last storm. As a consequence, we can postulate that a possible increase in the intensity of waves occurring from December to early March, along with a possible scenario of global change, would not restrict the productive period in the Bay of Biscay. However an extension of the period of storms later in March would delay the timing of the blooms as observed in March 2008 in most of the investigated area.
\end{abstract}




\section{Highlights}

- Satellite-derived suspended matters are investigated in relation with waves and tide $>$ Over the period 1998-2014, the highest turbidity is observed in the winter 2013-2014. The last storm of this windy winter occurs on March $3^{\text {rd }} 2014$. An early bloom occurred in the Bay of Biscay a few days after this last storm. Winter 2007-2008 stands out from the analysed time-series for its late storms.

Keywords: Suspended particulate matter, Satellite Ocean Colour, Waves effects, Climate, Algal blooms, North-West European shelf seas 


\section{Introduction}

The impacts of climate change on phytoplankton are expected to be diverse (Winder and Sommer, 2012). Amongst the consequences of an increase in sea surface temperature, we may observe a change in phytoplankton populations and their phenology through a temporal shift in the establishment of stratification, with the onset of the first blooms occurring earlier in the year (Sharples et al., 2013). The overall impact of an increase in temperature is nevertheless difficult to model, as the growth of the phytoplankton biomass results from an equilibrium between cell multiplication and grazing by herbivores (Behrenfeld and Boss, 2014). How grazers and prey will evolve in the future is therefore an open question. The first significant blooms of the year are mainly due to a temporal imbalance between increased growth within nutrient-rich waters and growing populations of grazers at the time at which both the mixed layer depth decreases and sun light increases. These blooms are generally well observed by satellite sensors as they occur on sunny days and in surface waters, light being limiting. The initiation time, the duration and the amplitude of the blooms are major ecological indicators of the marine environment, which can be derived at regional scale from remote-sensing data (Platt and Sathyendranath, 2008). The light available for phytoplankton development is the solar irradiance at the sea surface, which is attenuated during its path through the water column. At the end of winter, light attenuation within the water column is governed by the concentration of mineral suspended particulate matter (SPM). Therefore a variation in the SPM concentration, owing to the action of storms (Fettweiss et al., 2012; Rivier et al., 2012), has a direct effect on the phytoplankton growth.

Although it is not yet proven that the recent storminess observed in the North-Eastern Atlantic is directly induced by the global climate change, Wang et al. (2012) observed an increase in the frequency and lifespan of storms in Northern Europe since 1871. Amongst more dramatic aspects such as coastal damage and persistent flooding, the winter storms also affect the water clarity in coastal waters. It is this aspect that will be developed in this study. We will investigate the consequences of the exceptional run of storms observed in Western Europe from late December 2013 to early March 2014 (Sligo et al., 2014) on the timing of the phytoplankton blooms in late winter and at the beginning of spring. When investigating the hydro-climatic conditions in the North-East Atlantic in winter, it is very usual to refer to the North-AtlanticOscillation (NAO) index. Positive anomalies of NAO at this season are associated with strong 
westerly winds and wetter/milder weather over Western Europe. With a mean index of 2.3 for the months of December 2013 to March 2014, the station-based NAO (Hurrell, James \& National Center for Atmospheric Research Staff, 2014) was the highest observed in the period 1998-2014, during which ocean colour sensors have been available on an operational basis. We will take advantage of the opportunity brought to us by this windy winter to investigate the effects of exceptional levels of turbidity in winter on the phytoplankton blooms.

The area under study concerns the continental shelf of the Celtic Sea, the English Channel and the Bay of Biscay (Fig. 1). Garcia-Soto and Pingree (2009) describe the regional characteristics of the seasonal cycle of chlorophyll and its yearly variability along a ferry-line, including satellite observations, in the Bay of Biscay and the Western English Channel. In this study we focus on the timing of the spring blooms in relation to the water clarity, whose indicator will be the satellite-derived SPM content. The spring bloom is a critical event in the marine food chain, representing the first significant supply of phytoplankton following the winter. The timing of the bloom is therefore critical for the growth and survival of the diverse components of the marine ecosystem. The onset of the bloom is closely dependent on the stability of the surface layer and on the attenuation of the diffuse descending light, $\mathrm{K}_{\mathrm{PAR}}$. For this reason, Capuzzo et al. (2013) partition the North-Sea in distinct ecohydrodynamical regions based upon their ability to stratify or not and also their clarity, through the attenuation coefficient of light, $\mathrm{K}_{\mathrm{PAR}}$. Here, we will consider four stations related to different hydrodynamical and biological conditions considered as representative of the main situations encountered in the studied area, without being exhaustive. 


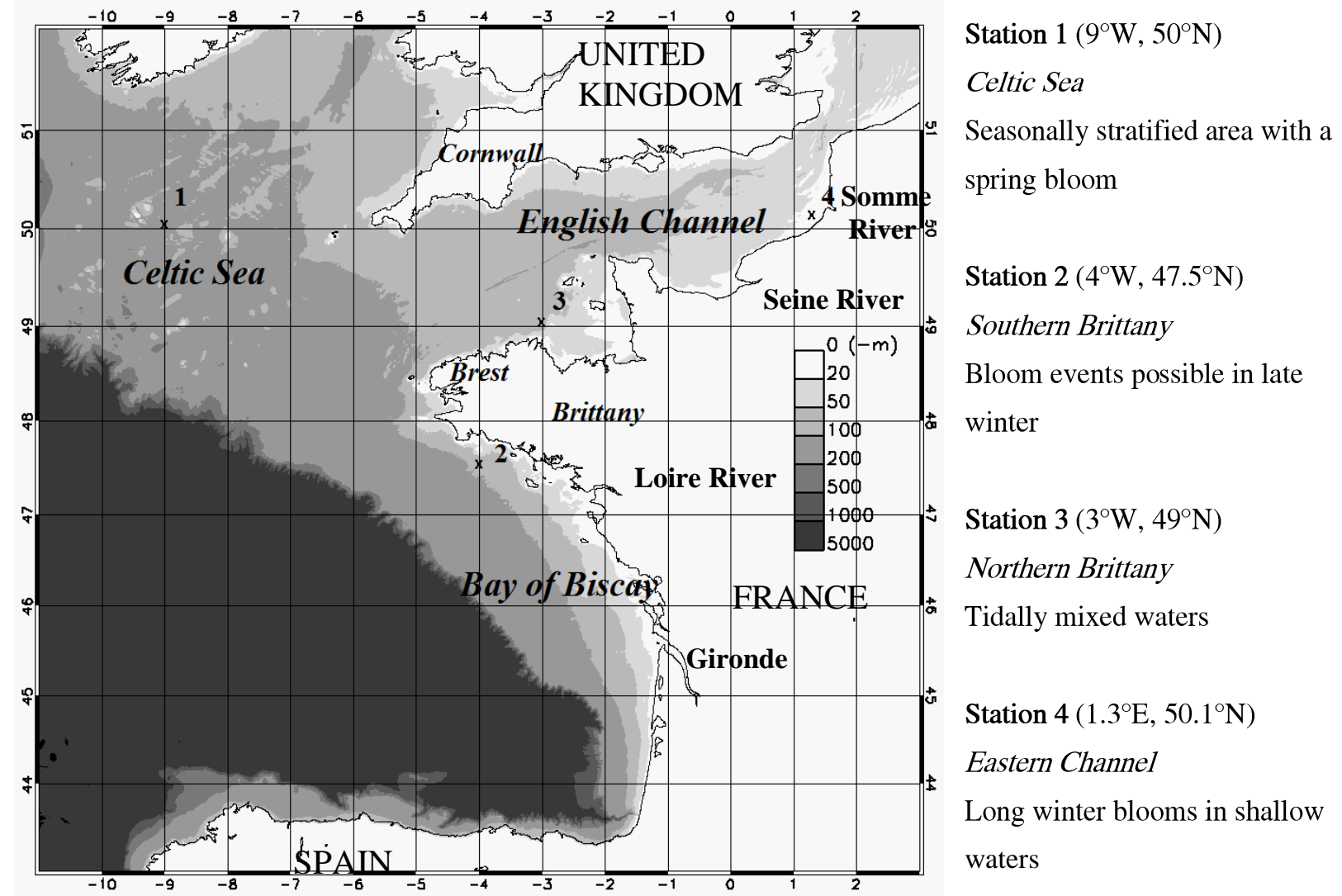

Fig. 1. The studied area and the locations of the four stations analysed

We will analyse the effect of the winter storms on the resuspension of suspended particulate matter using the model developed by Rivier et al (2012). This very simple statistical model, based on satellite-derived SPM, gives a quantitative assessment of the relation between tide, waves and resuspension over the English Channel. In this model, the "wave" variable groups together their effect on the resuspension of sediment, through bottom shear stress, windgenerated turbulence and the settling of particles.

Despite the high variability in the hydrodynamical characteristics of our area we will only consider four sites in detail. From the west, moving eastward, these points are noted 1 to 4 on Fig. 1. Station $1\left(9^{\circ} \mathrm{W}, 50^{\circ} \mathrm{N}\right)$ is located in the Celtic Sea, where the exposure to the westerly waves is high and where the first bloom occurs relatively late each year, often in April (Pingree, 1980, Rees et al., 1999). At this location we may consider that the first bloom occurs in relation to near surface stabilisation after transition to a positive net heat flux in spring, similarly to station L4 situated off Plymouth in the Western English Channel (Smyth et al., 2014). The second site $\left(4^{\circ} \mathrm{W}, 47.5^{\circ} \mathrm{N}\right)$ is located off the southern coast of Brittany. At this location, haline stratification may occur early due to the fresh water discharge of the Loire River, as in March 2000 when a late winter bloom was captured by SeaWiFS imagery. Hydrological conditions 
prior to this bloom were described in detail by Gohin et al. (2003). The third site is located in the middle of the Channel, where the tidal current is the major driver of resuspension (Bréhat Point 3 at $\left.3^{\circ} \mathrm{W}, 49^{\circ} \mathrm{N}\right)$. The last site $\left(1.3^{\circ} \mathrm{E}, 50.1^{\circ} \mathrm{N}\right)$ is located in the eastern part of the English Channel, near the French coast, where a shallow bathymetry permits an early initiation of the phytoplankton growth, as soon as the end of February. An overview of the chlorophyll-a cycle over the region, derived from satellite reflectance or observed in-situ by the Ifremer REPHY network of phytoplankton monitoring, is described in Gohin (2011). Table 1 gives the main characteristics of the environment surrounding the four sites.

\begin{tabular}{|c|c|c|}
\hline $\begin{array}{l}\text { Station and } \\
\text { Location }\end{array}$ & $\begin{array}{l}\text { Hydrological characteristics } \\
\text { of the surrounding waters }\end{array}$ & Spring bloom in the area \\
\hline $\begin{array}{ll}1 & \text { Celtic Sea } \\
& 9^{\circ} \mathrm{W}, 5^{\circ}{ }^{\circ} \mathrm{N}\end{array}$ & $\begin{array}{l}50-100 \text { m depth } \\
\text { Numerous shoal patches } \\
\text { Seasonally stratified }\end{array}$ & $\begin{array}{l}\text { The spring bloom generally occurs } \\
\text { in April with moderate Chl-a } \\
\text { concentration } \\
\left(4-6 \mathrm{~m} \mathrm{~m}^{-3}\right)\end{array}$ \\
\hline $\begin{array}{ll}2 & \text { Southern } \\
& \text { Brittany } \\
& 4^{\circ} \mathrm{W}, \mathbf{4 7 . 5}^{\circ} \mathrm{N}\end{array}$ & $\begin{array}{l}100-200 \text { m depth } \\
\text { Region of freshwater influence } \\
\text { at the end of winter }\end{array}$ & $\begin{array}{l}\text { Blooms may occur in late winter, } \\
\text { particularly after a rainy winter, as } \\
\text { in March } 2000 \text { (Gohin et al., 2003) } \\
\text { Chl-a concentration may reach } 10- \\
20 \mathrm{mg} \mathrm{m}^{-3} \text { at that period. }\end{array}$ \\
\hline $\begin{array}{ll}3 & \text { Northern } \\
& \text { Brittany } \\
& 3^{\circ} \mathrm{W}, 49^{\circ} \mathrm{N} \\
\end{array}$ & $\begin{array}{l}50 \text { m depth } \\
\text { Strong tidal current } \\
\text { Well-mixed }\end{array}$ & $\begin{array}{l}\text { No marked bloom in these well- } \\
\text { mixed waters }\end{array}$ \\
\hline $\begin{array}{ll}4 & \text { Eastern } \\
\text { English } \\
\text { Channel } \\
\\
\mathbf{1 . 3}^{\circ} \mathbf{E} \\
\mathbf{5 0 . 1}^{\circ} \mathbf{N}\end{array}$ & $\begin{array}{l}15 \mathrm{~m} \text { depth } \\
\text { Mixed area, with strong } \\
\text { incoming nutrient flux from } \\
\text { the south (Seine river) }\end{array}$ & $\begin{array}{l}\text { In these very shallow waters, the } \\
\text { phytoplankton growth may start as } \\
\text { soon as February, developing } \\
\text { regularly until April and reaching } \\
\text { very high levels in Chl-a ( } 50 \mathrm{mg} \mathrm{m} \text { - } \\
3 \text { often during phaeocystis colony } \\
\text { blooms) }\end{array}$ \\
\hline
\end{tabular}

Table 1. Main characteristics of the environment surrounding the four sites 


\section{Data and Methods}

\subsection{Satellite data}

Two sets of images will be considered in this study. The first one, which is our main data set providing non-algal SPM and Chlorophyll-a, is derived from Ocean Colour reflectance. The second one, Surface Solar Irradiance (SSI), is obtained from the bi-directional reflectance measured by geostationary satellites.

\section{The Ocean Colour products}

The chlorophyll-a is obtained from the Ifremer OC5 algorithm tuned for the coastal waters investigated in this study (Gohin et al., 2002; Gohin, 2011).

The non-algal SPM is processed through the procedure described in Gohin et al (2005) and modified in Gohin (2011). Although turbidity, with its strong relation to the backscattering properties, would be a well-adapted parameter to represent suspended particles, we have chosen to use SPM, which is a standard variable in hydro-sedimentary models. Satellite-derived SPM has also been used for assessing the output of different sediment models (Cayocca et al., 2014; Sykes and Barciela, 2012). For adjusting the parameters of the statistical model linking SPM to waves and tides, daily raw $1.2 \mathrm{~km}^{2}$ MODIS non-algal SPM fields are considered. These products cover the period from January 2008 to April 2014, corresponding to the availability of spatially homogeneous wave data sets at Ifremer.

A second set of products will also be considered for describing the variability observed on a longer period, from January 1998 to April 2014. This latter dataset is based on the dailyinterpolated L4 Ifremer SPM products, derived from SeaWiFS/MERIS/MODIS/VIIRS (Saulquin et al., 2011). To build up these products we first consider daily fields of anomalies, the anomaly being defined as the deviation to the daily climatological mean of SPM. Then the anomalies are interpolated on our regular grid at a resolution of $1.2 \mathrm{~km}^{2}$ by kriging (objective analysis). The final product is obtained by addition of the interpolated anomaly to the climatological mean of the day (our first-guess field). The interpolation makes use of up to eleven products for each 
sensor (up to five days before and after the considered day). The main advantage of these interpolated products is the availability of daily observations at our four selected locations.

Finally a third product, that we will name the analysed L4, will also be considered in this study. These new analysed non-algal SPM fields are obtained by the procedure described in Gohin et al. (2014) which uses daily simulated fields derived from the statistical model as a first-guess, from which are derived the anomalies, rather than the climatological mean as in the ordinary L4 field. The main interest of this new L4 analysis is to incorporate a priori information coming from the wave fields.

The semi-analytical model used to retrieve non-algal SPM from satellite reflectance is described in Gohin et al. (2005) and Gohin (2011). The effect of the phytoplankton on the absorption and backscattering properties is approached through a preliminary estimation of the chlorophyll concentration by the OC5 algorithm (Gohin et al., 2002). Non-algal SPM is estimated from radiance at $555 \mathrm{~nm}$ or $670 \mathrm{~nm}$ depending on the SPM level retrieved $\left(4 \mathrm{gm}^{-3}\right)$. SeaWiFS, MERIS (MEGS8.1) and MODIS reflectances are the up to date products available after reprocessing by the agencies in 2012. Since 2012, MODIS products are the current L2 products available through subscription to the OceanColor NASA/GSFC Centre.

\section{The Sea Surface Solar irradiance (SSI)}

The SSI is the solar irradiance (in Watt $\mathrm{m}^{-2}$ ) reaching the Earth surface in the 0.3-4 $\mu \mathrm{m}$ band. The processing chain for deriving SSI from the data of MSG (METEOSAT Second Generation) satellites is fully described in the SSI Product Manual, available on the OSI SAF web server (EUMETSAT, 2006). The different steps in the processing include the calibration of the satellite visible count into bi-directional reflectance, the conversion from the narrow band of the radiometer spectral filter to the broadband of the solar spectrum, the conversion from the broadband bi-directional reflectance to the Top of Atmosphere (TOA) albedo independent of the satellite viewing angles. Finally, the SSI is obtained as function of the TOA albedo, the atmospheric transmittance (out of cloud) and the surface albedo. The validation of the SSI products provided by the OSI SAF is described in Le Borgne et al. (2006) 


\subsection{Wave data}

Waves are represented by the significant wave height, $H_{S}$, provided by Fabrice Ardhuin through the IOWAGA (Integrated Ocean Waves for Geophysical and Other Application) project (http://wwz.ifremer.fr/iowaga) and Previmer, the French pilot project of operational coastal oceanography. The significant wave height is obtained through the WAVEWATCH III model (Filipot and Ardhuin, 2012; Ardhuin et al., 2009). The model is forced by operational ECMWF wind analysis at a resolution of $1 / 4^{\circ}$ or better, with a time step of 6 hours (3 hours since January 2013). We have considered the maximum $H_{S}$ observed during the day as the input of waves into the model

\subsection{SPM model}

The SPM model is derived using the procedure developed by Rivier et al. (2012) for the English Channel. In their article, the authors proposed several formulations expressing SPM as a function of waves and tide. These formulations are all based on a multiplying effect of tide intensity and significant wave heights applied to a seasonal component, which can be the average SPM, the inverse of the Chlorophyll-a or the Sea Surface Temperature. The seasonal effect takes into account the stratification of the surface water as well as the biological state of the medium more or less favourable to aggregation by TEPs (Transparent Exopolymer Particles), owing to phytoplankton activity (Klein et al., 2011), and therefore to settling velocities. In this study, as the original idea is not to describe the mechanisms underlying the seasonal effect, we use the average SPM of the day $\overline{S P M_{j}}$ as the seasonal component. As in Rivier et al. (2012), $\overline{S P M_{j}}$ is obtained by bilinear interpolation from a monthly climatology of MODIS SPM calculated over the 2003-2013 period.

The model is: $S P M_{j}=a \overline{S P M}_{j} T_{j}^{\alpha} H_{S T j}^{\beta}$ where $\mathrm{j}$ is the considered day (1)

$T_{\mathrm{j}}$ is the tidal intensity derived from the tidal coefficient of SHOM (Service Hydrographique et Océanographique de la Marine), which corresponds to the tidal range in Brest (Brittany, France). The SHOM coefficients are integrated over three days: $\mathrm{j}-2, \mathrm{j}-1, \mathrm{j}$, with an equal weight of $1 / 3$. $H_{S T}$ is a time-integrated significant wave height taking into account retention of the wave effect. 
$H_{S T}$ is calculated by integrating the daily maximum significant wave height $H_{S}$ over $\mathbf{n}$ days Equation (2) gives our weighting coefficients, as in Rivier et al. (2012).

$H_{S T j}=\sum_{i=0}^{n-1} H_{s j-i}(n-i) 2 / n(n+1)$

In Rivier et al., the number $\mathbf{n}$ of days for integration was fixed to 25; this value was adapted to the English Channel but, here, we will consider also a shorter period for integration as the effect of the waves on the continental shelf of the Bay of Biscay, directly facing the Atlantic storms, is expected to be shorter. 10 or 25 days will be chosen following the determination coefficient of the adjusted parameters of the model on a pixel-by-pixel basis. 


\section{Results and discussion}

\subsection{Average conditions in waves, SPM and chlorophyll-a}

The wave field appears to be very variable temporally and spatially within the area, the highest $H_{S}$ being observed in the deeper and more exposed waters of the Celtic Sea and the Bay of Biscay.
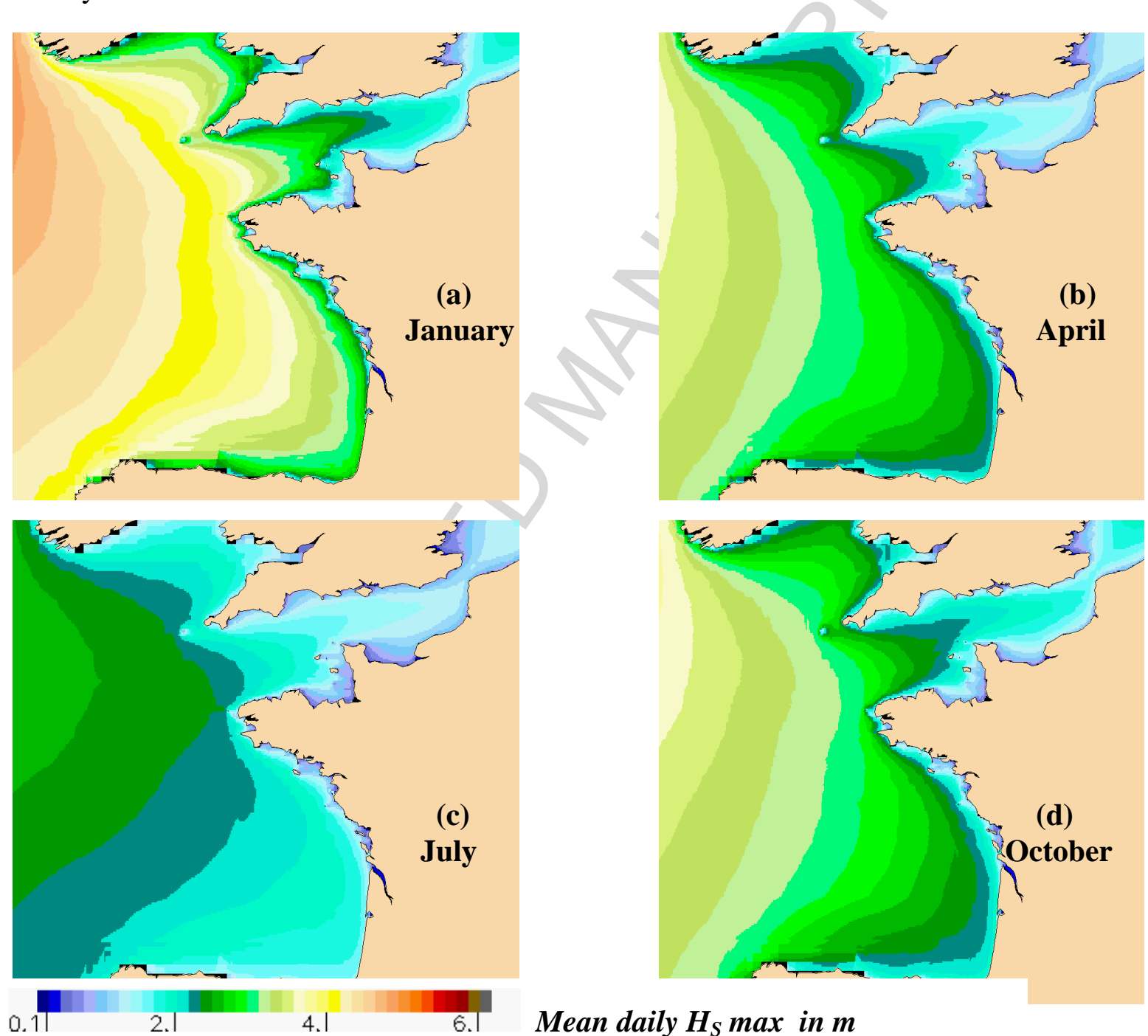

Mean daily $H_{S} \max$ in $m$

Fig. 2. Monthly average of the significant wave height $H_{S}$ (2008-2013): (a) January; (b) April; (c) July; (d) October

Fig. 2 shows the monthly averages of $H_{S}$ at different seasons. The difference between the averaged waves in January (Fig. 2a) and July (Fig. 2c) reflects the strong seasonal variability. 

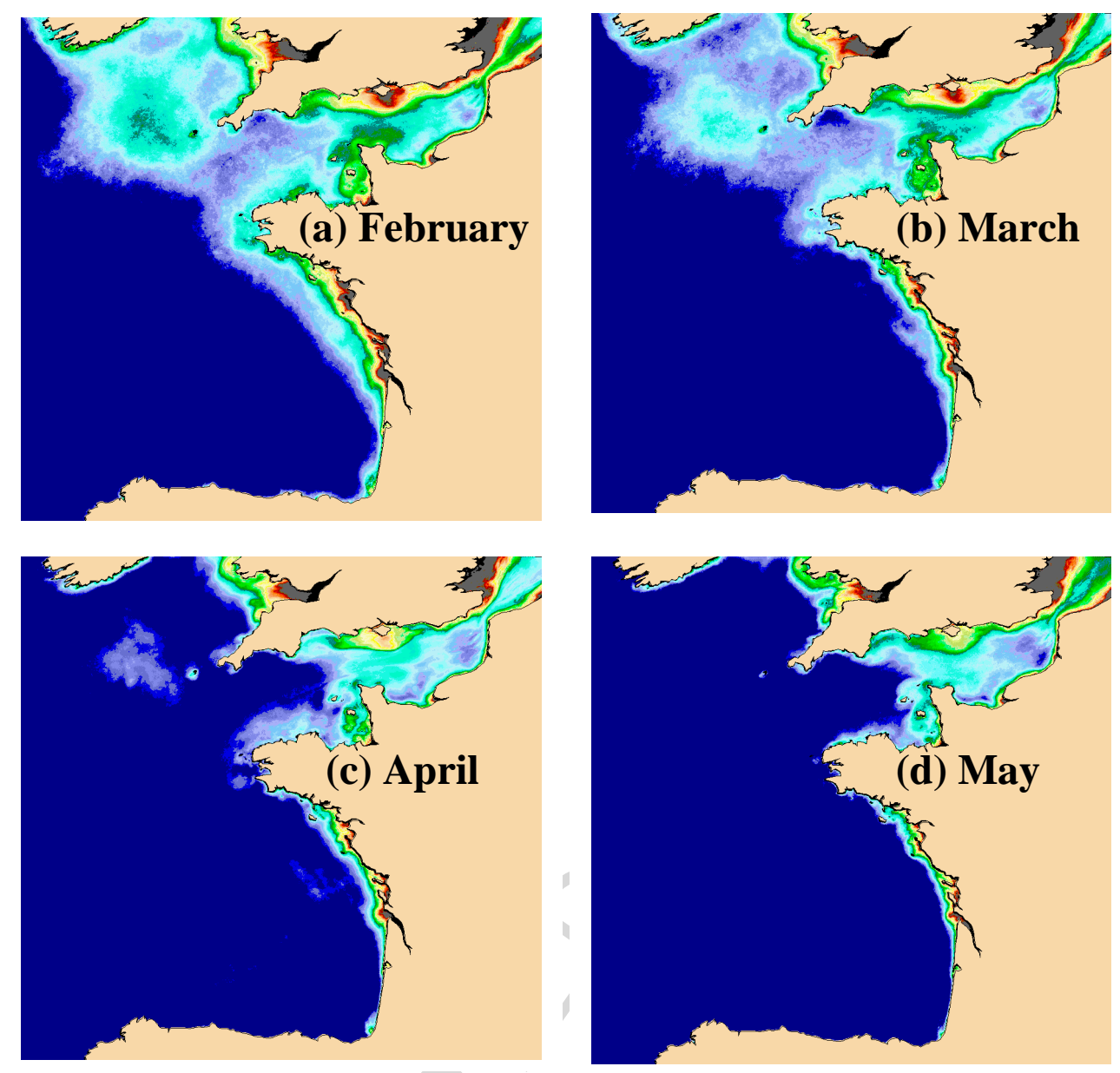

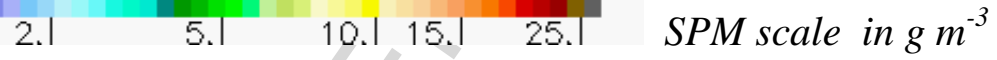

Fig.3. Monthly average of the non-algal SPM from MODIS/AQUA (2003-2013).

(a) February; (b) March; (c) April; (d) May

Fig. 3 shows the seasonal variation of non-algal SPM through the averages calculated on 4 months (February to May) during the 2003-2013 period.

Fig. 4 shows the average of the chlorophyll-a concentration processed through the OC5 algorithm applied to MODIS data from March to May (2003-2013). It has to be noticed that there exists a strong annual variability around the averaged Chlorophyll-a fields shown on Fig. 4 for the Bay of Biscay in late winter (March). At this season, some strong blooms may occur in the stratified waters of the river plumes at different locations from one year to another (Gohin et al., 2003). Conversely to the Bay of Biscay, the English Channel environment appears to be more driven by the bathymetry and the tide, leading to basic features constant through the years (Ménésguen and Gohin, 2006). High concentration in chlorophyll-a are observed in the Eastern 
English Channel in the average images of March to May (Fig. 4a-b) where is located our station 4.
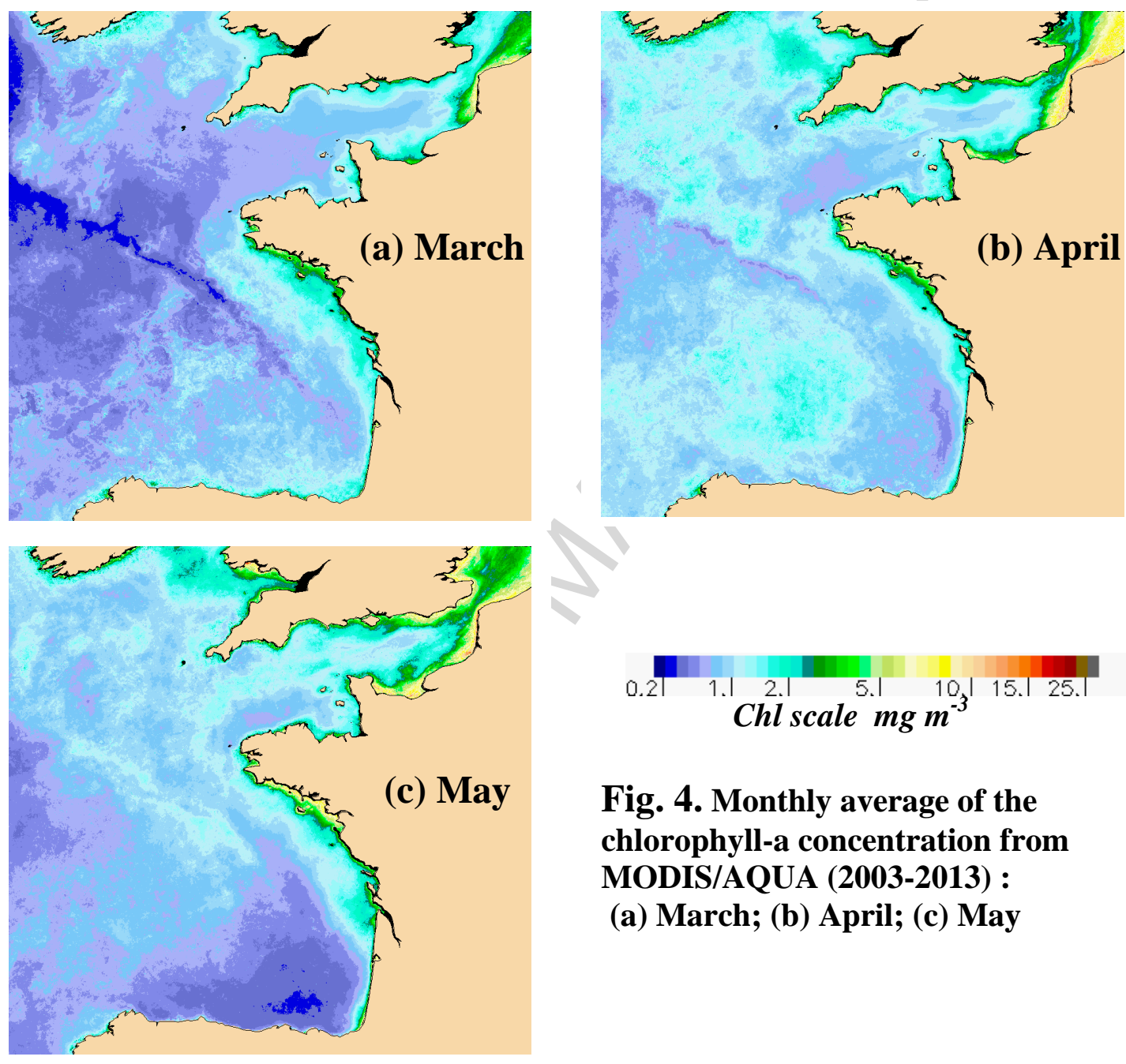

Fig. 4. Monthly average of the chlorophyll-a concentration from MODIS/AQUA (2003-2013) : (a) March; (b) April; (c) May

\subsection{The parameters of the statistical model}

The parameters of the model (1) have been estimated for every pixel. After log-transformation of SPM this multiplicative model results in a linear regression whose parameters and coefficient of determination have been classically estimated, as in Rivier et al. (2012). In complement to the simplicity of the transformed model, the logarithmic transformation is particularly adapted to observation errors following a lognormal law, with a strong dissymmetry around the mean. Some high values of non-algal SPM observed in winter near the coast after kriging (L4 products) have relatively less weight after log-transformation in the minimisation procedure used for retrieving the parameters of the model. For preventing any contamination of the SPM by coccoliths (Morozov et al., 2013; Shutler, 2013) data from April to July have been excluded from our data set. 

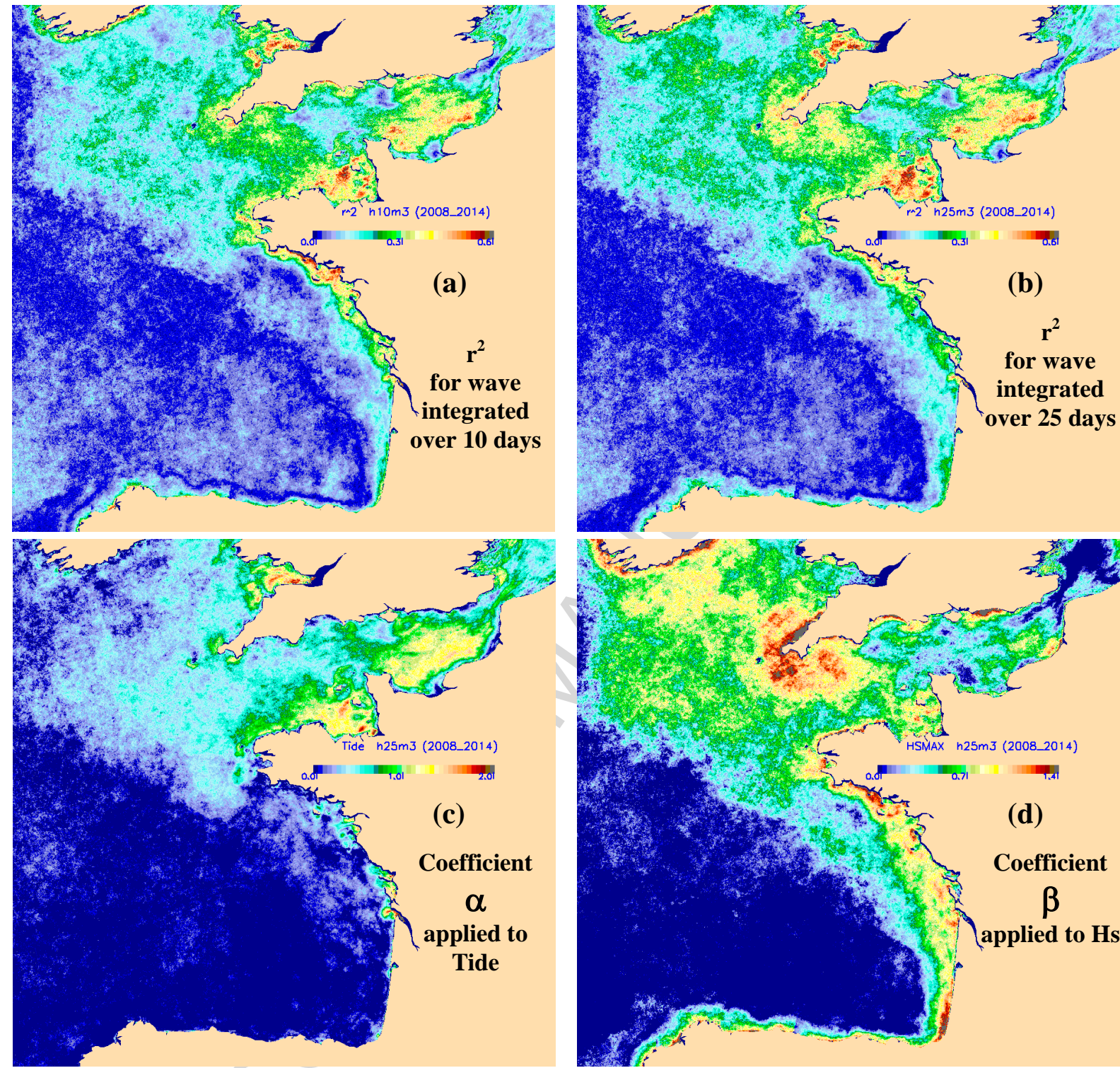

Fig. 5. Coefficients of the statistical model: determination coefficient for waves integrated over 10 days (a), 25 days (b); power coefficients applied to tide (c) and waves (d) for the waves integrated over 25 days

Fig. 5a and 5b show the determination coefficient of the model for two integration times applied to waves, 10 or 25 days. As expected, the determination coefficients are better for the 10-day model along the shores of the Bay of Biscay whereas there is no clear difference in the determination coefficient of the two integration periods in the English Channel. Fig. 5c and 5d show the coefficient estimated for Tide and $H_{S}$ respectively. The coast of the Cornish peninsula appears to be particularly sensitive to waves, as both the power coefficient applied to $H_{S}$ and the levels of $H_{S}$ are high within this area. 


\subsection{SPM in winter 2013-2014}

The model has been applied daily from 2008 to April 2014, when $H_{S}$ data are available. Fig. 6a-c show $H_{S}$ corresponding to the last storm of the winter 2013-2014, at the beginning of March 2014. The output image derived from the statistical model applied to the tide coefficient and the integrated $H_{S}$ on March $3^{\text {rd }}$ is shown on Fig. 6d. This image is similar to the interpolated (L4) SPM product of the same day (Fig. 6e) but with smoother and less extreme values as commonly observed for model outputs. Fig. 6f shows the new analysed L4, an intermediary product between the smooth model output and the traditional interpolated L4.
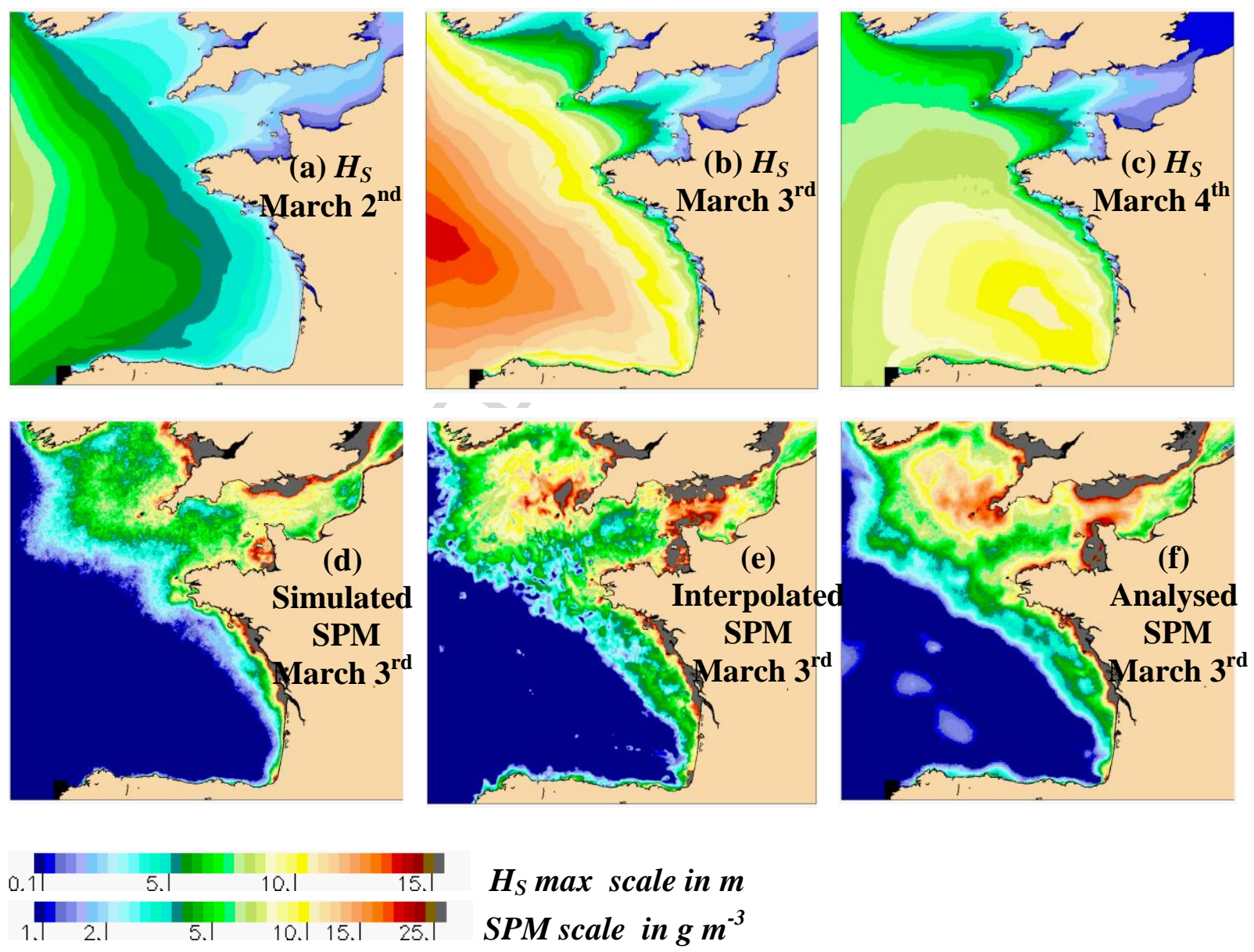

Fig. 6. Situation of the last winter storm: (a-c) waves $\left(H_{S}\right)$ on March $2^{\text {nd }}$ to $4^{\text {th }}$; (d) output of the statistical model of SPM on March $3^{\text {rd }}$; (e) interpolated (L4) SPM; (f) new analysed L4 SPM

Fig. 7 shows the observed and modelled SPM together with $H_{S}$ at our four selected locations from January 2008 to April 2014. Fig. 7a shows the times series of SPM and $H_{S}$ at the Celtic Sea location. The simulated SPM reaches its highest level in January and February 2014 following two strong storms at the end of December and in late February. Green stars on the figure indicate the days when $H_{S}$ exceeded the highest integrated $H_{S T}$ of the series. If we consider both the level 
of the integrated $H_{S}$ and the number of stormy days, the winter 2013-2014 appears quite different from the winter 2012-2013. We notice that at this point the statistical model (in red) underestimates considerably the high SPM observed in the first months of 2014 (in blue). We may also observe a strong relationship between the integrated waves (in green) and SPM in these extreme meteorological conditions. Fig. $7 \mathrm{~b}$ shows the same time series observed or modelled at our station in Southern Brittany. Once again, the highest SPM have been observed during the 2013-2014 winter. At our Northern Brittany station, SPM is well regulated by the tide (see the red curve following the spring-neap cycle on Fig.7c) although the effect of waves are also conspicuous in the SPM levels of the winter 2013-2014. The eastern channel station (Fig. 7d) is much less affected by waves. In this area the levels of observed SPM can be very variable, particularly in winter. This can be explained by the proximity of the Somme River and the effect of interpolation in a near shore area. 

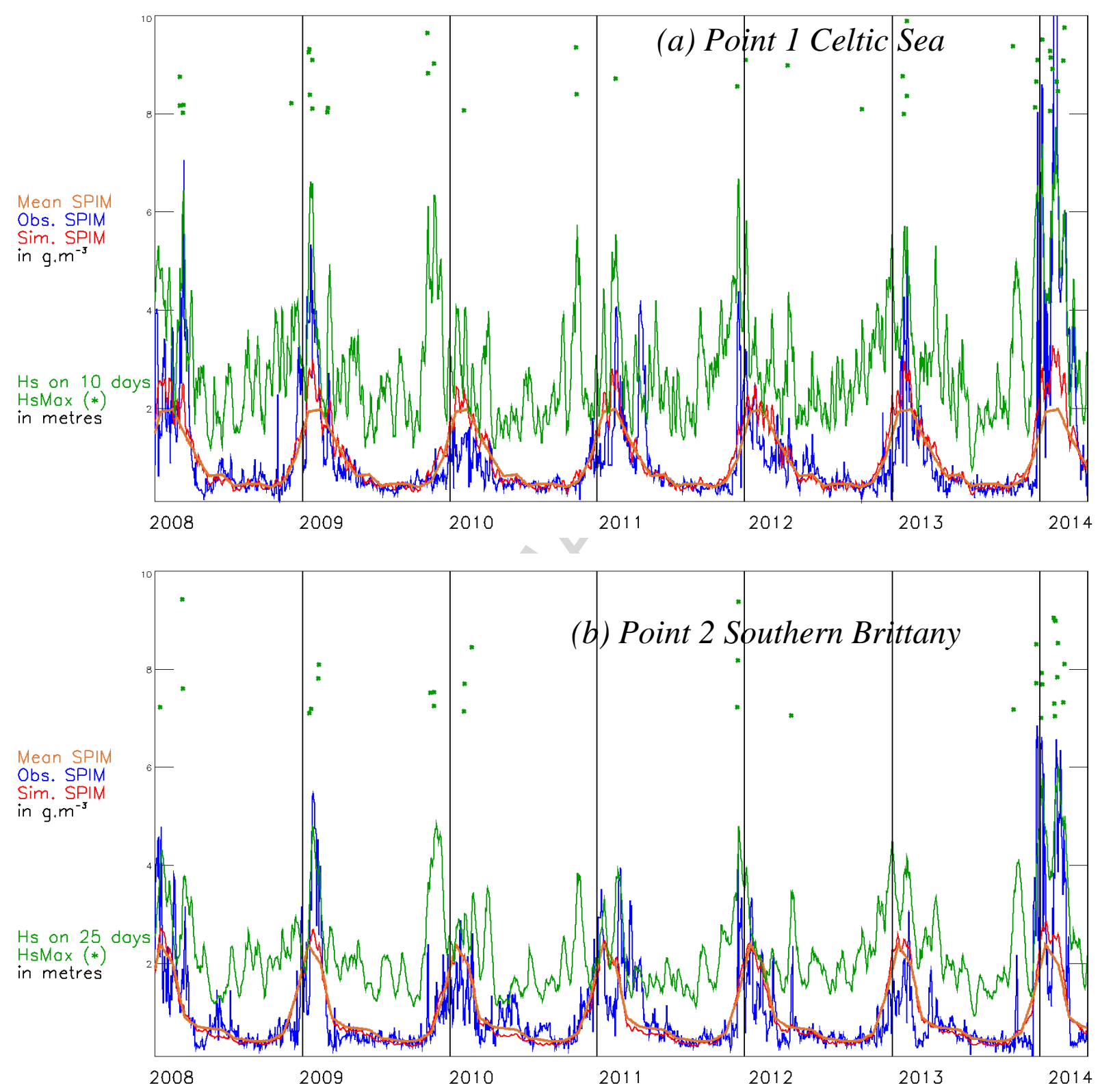

Fig. 7. Observed (blue) and modelled (red) non-algal SPM from January 2008 to April 2014. (a) Celtic Sea; (b) Southern Brittany.

Integrated $H_{S}$ is shown in green. The green stars plot the daily $H_{S}$ superior to the maximum integrated $H_{S}$ observed on the green curve. The numerous stars in the winter 2013-2014 are related to the successive storms affecting the region. Conversely to this latter winter, the winter 2010-2011 and 2012-2013 were much calmer, particularly in southern Brittany. 

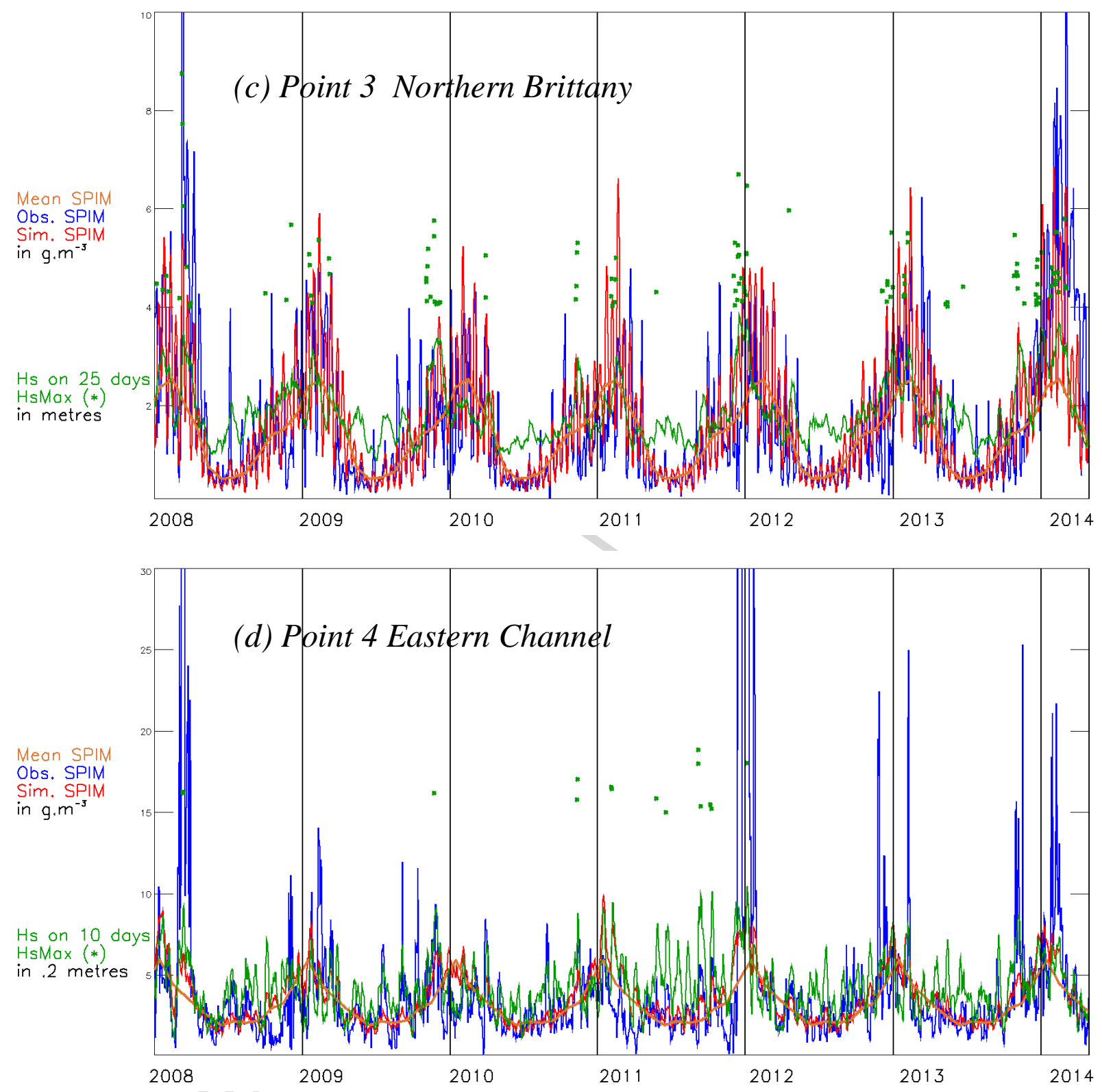

Fig. 7. (c) Northern Brittany; (d) Eastern Channel 
Fig. 8 shows time series of observed SPM, during the period 1998-2014. Once again, in this longer time series, winter 2013-2014 shows the highest levels.
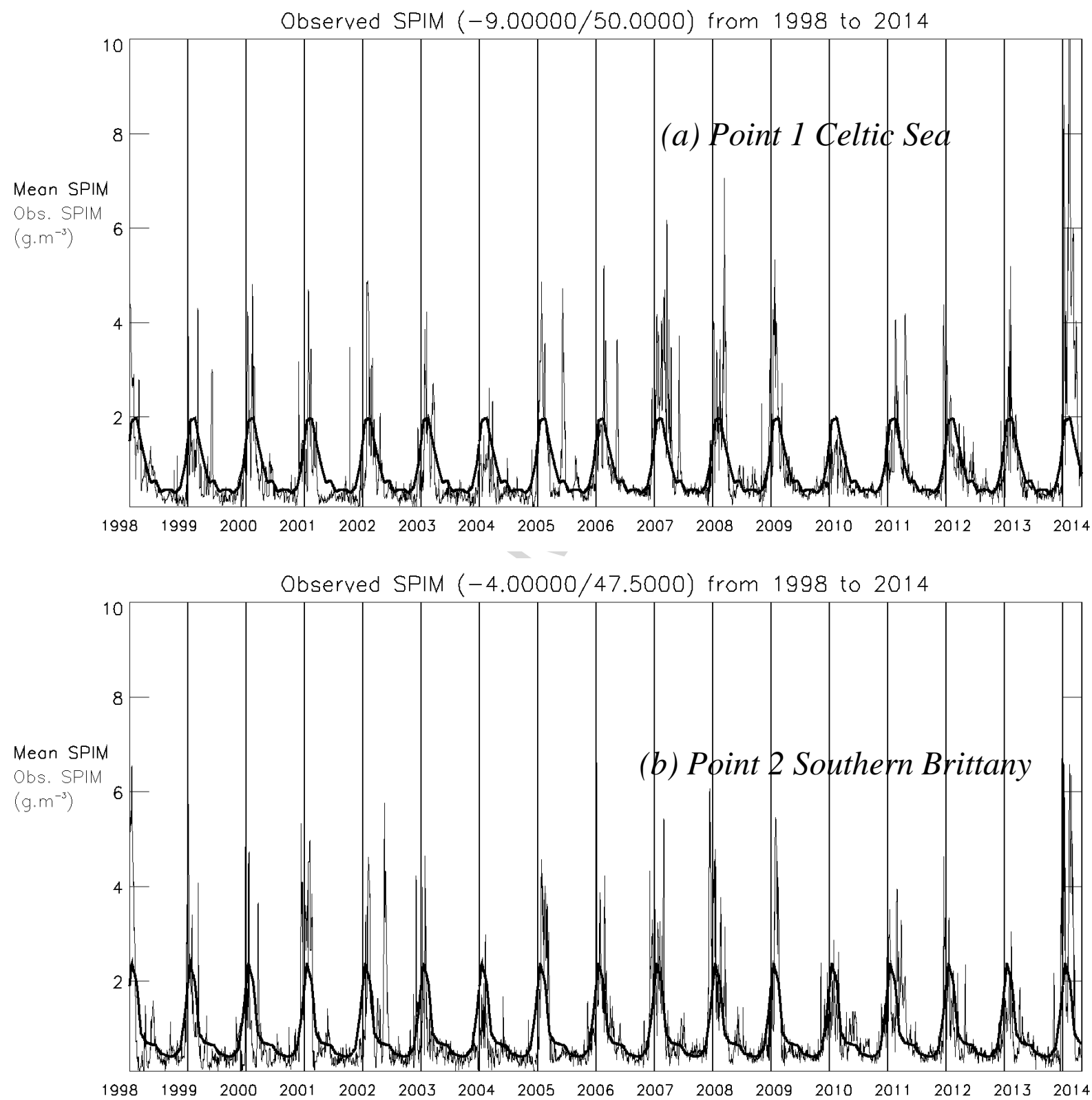

Fig. 8. Observed non-algal SPM from January 1998 to April 2014 in the Celtic Sea and in Southern Brittany. Bold curve shows the mean non-algal SPM. (a) Celtic Sea; (b) Southern Brittany

\subsection{Chlorophyll-a at the end of winter 2013-2014}

Fig. 9 shows the Chlorophyll concentration at our four sites from February to March. This figure presents also the observed SPM for the same months. On Fig. 9a, corresponding to the station in the Celtic Sea, the bloom occurs every year in April, except in 2008 when Chlorophyll signal was absent. The bloom occurs approximately when the SPM concentration falls below a 
threshold of about $1 \mathrm{~g} \mathrm{~m}^{-3}$. On our station off Southern Brittany, a strong chlorophyll peak appears early, in the first part of March 2014, just after a steep drop in SPM concentration. The time series of chlorophyll at the northern Brittany station doesn't show any distinctive feature in 2014; as usual in these well-mixed waters, the chlorophyll level is low. In the eastern English Channel station, shown on Fig. 9d, the blooms occur generally when SPM concentration drops to around $4 \mathrm{~g} \mathrm{~m}^{-3}$. This level was reached in mid-March 2014 and phytoplankton started to develop at that time, similarly to spring 2012 but at a relatively low pace. Overall, the initiation day of the phytoplankton blooms in the late winter of 2014 doesn't stand out significantly from other years, even showing an early bloom in Southern Brittany.
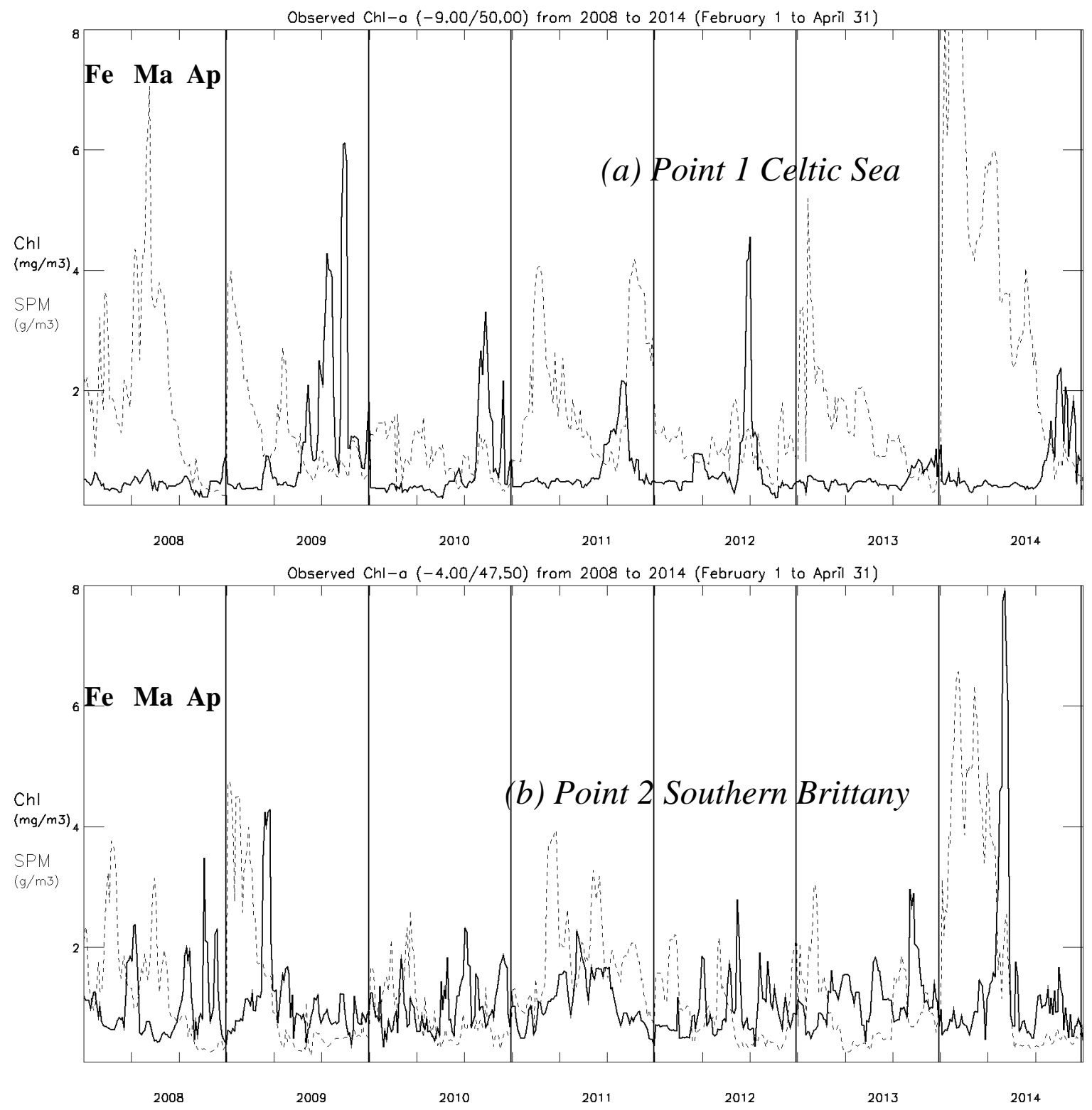

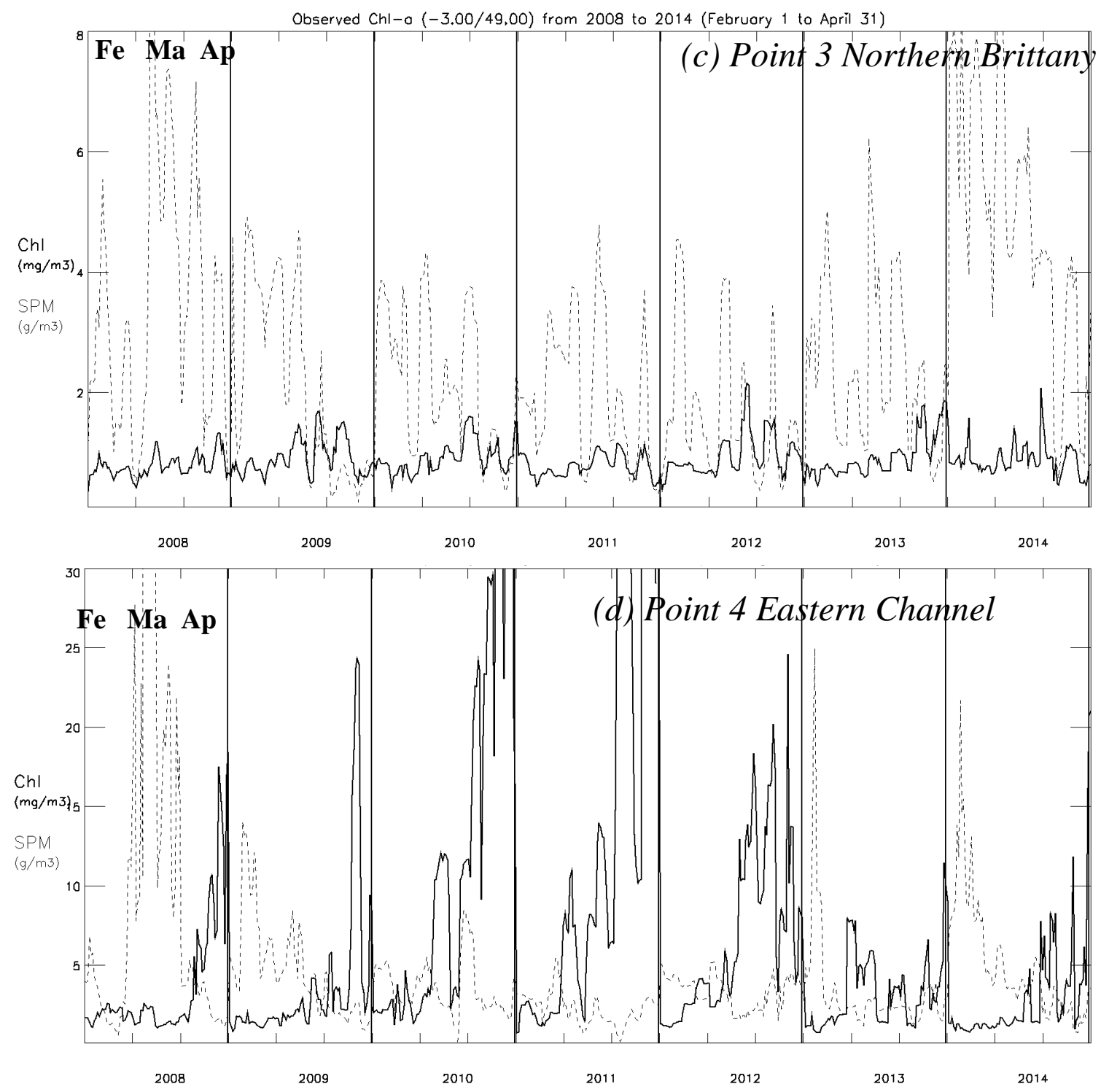

Fig. 9. Observed chlorophyll-a (bold line) and non-algal SPM (doted line) from 2008 to 2014 for the months of February, March, April at the four virtual stations. (a) Celtic Sea; (b) Southern Brittany; (c) Northern Brittany; (d) Eastern Channel

\subsection{Winter storms and late winter storms}

Through this description of the situation at the end of the winter 2013-2014 we conclude that there is a low impact of the high content of sediment at the beginning of March on the initiation of the blooms. On the contrary, there is a positive effect on the development of early blooms in Southern Brittany through enhancement in the haline stratification of the waters (Gohin et al., 2003). Fig. 10 shows the largest late winter blooms observed on the 1998-2014 period through interpolated chlorophyll concentration maps on March $14^{\text {th }} 2014$ together with the situation on March $12^{\text {th }} 2000$ and March $3^{\text {rd }} 2013$. The hydrological conditions of the March 2000 bloom 
have been well documented in Gohin et al. (2003). This bloom was mainly due to a large diatom Coscinodiscus wailesii whose development occurred in the stratified waters of the distal plume of the Loire River and other rivers of Southern Brittany.
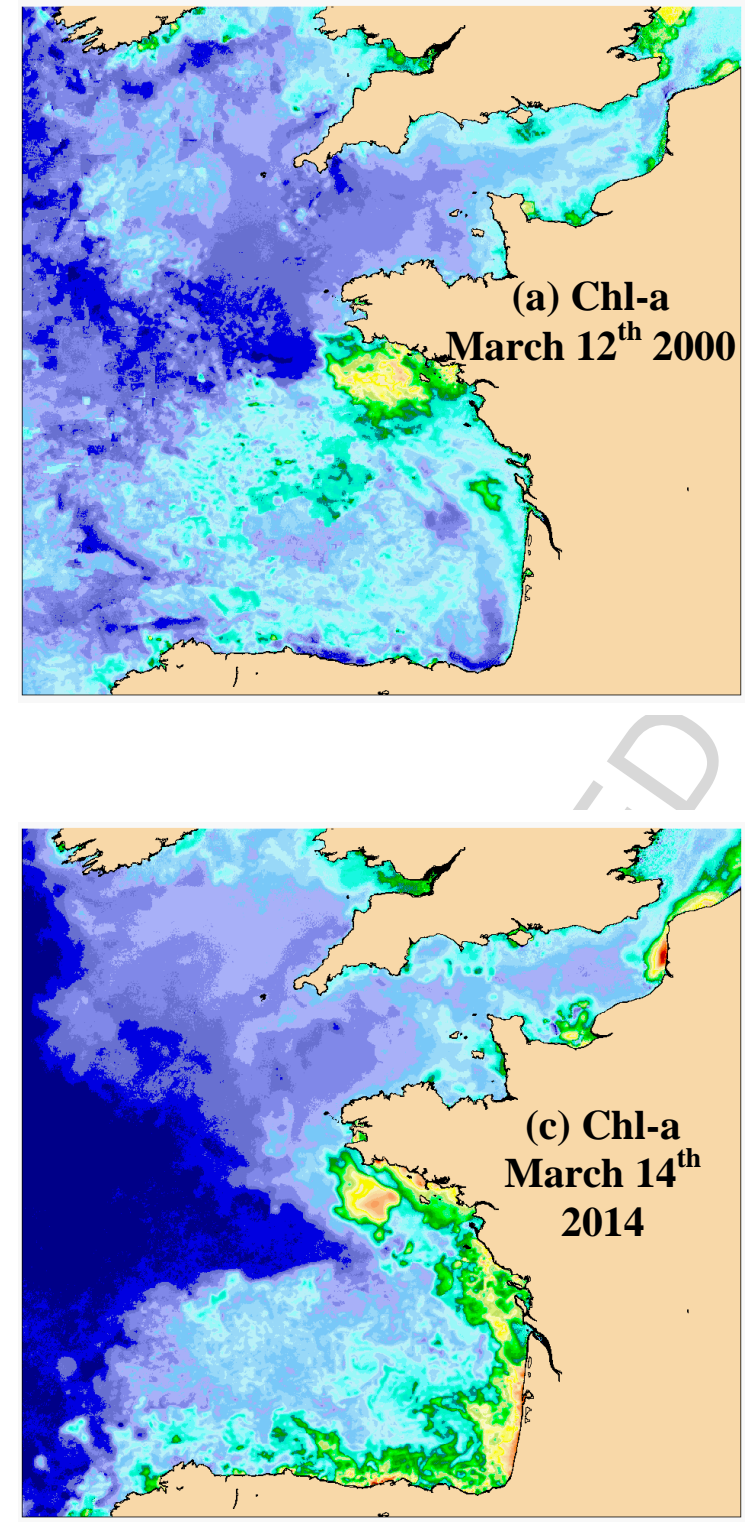
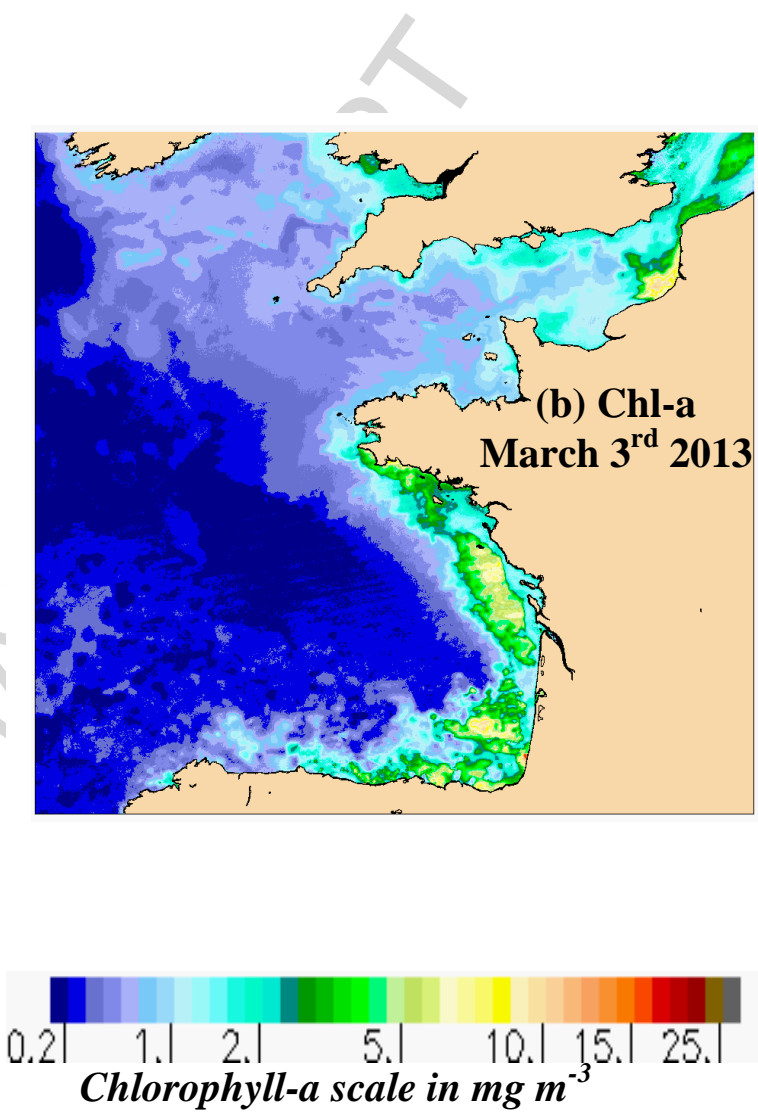

Fig. 10. The largest early blooms in the Bay of Biscay observed from 1998 to 2014. (a) interpolated Chlorophyll-a on March $15^{\text {th }} 2000$, (b) on March $3^{\text {rd }} 2013,\left(\right.$ c) on March $14^{\text {th }}$ 2014.

The 2013 bloom covers an area southern to our station in southern Brittany.

The March 2014 situation is very similar to March 2000. Along with the storms, high rainfall increased the river outflows significantly in February and at the beginning of March (Fig. 11). Storms and high SPM loads are observed in March 2008 (Stations 1, 3 and 4 on Fig. 9), later than in 2014 (last storm at the beginning of March). Fig. 12 reflects the impact of late storms on the dynamics of SPM through the 2008 and 2014 examples. This figure is obtained from our new analysed L4 SPM products. Whereas the 2014 SPM field (Fig. 12b and Fig. 12c) follows the mean seasonal trend to attenuation, late storms in 2008 inverse the trend leading to a higher 
content in surface SPM and therefore to a lower water clarity and a weaker stratification hampering potential blooms. Together with higher $H_{S}$ in March 2008, the late winter storms result in lower solar irradiance (Figure 13). Despite the high SPM content at the beginning of March 2014, a week of calm and sunny days (5-12 March) enabled the initiation of the bloom in the surface waters off Southern Brittany.
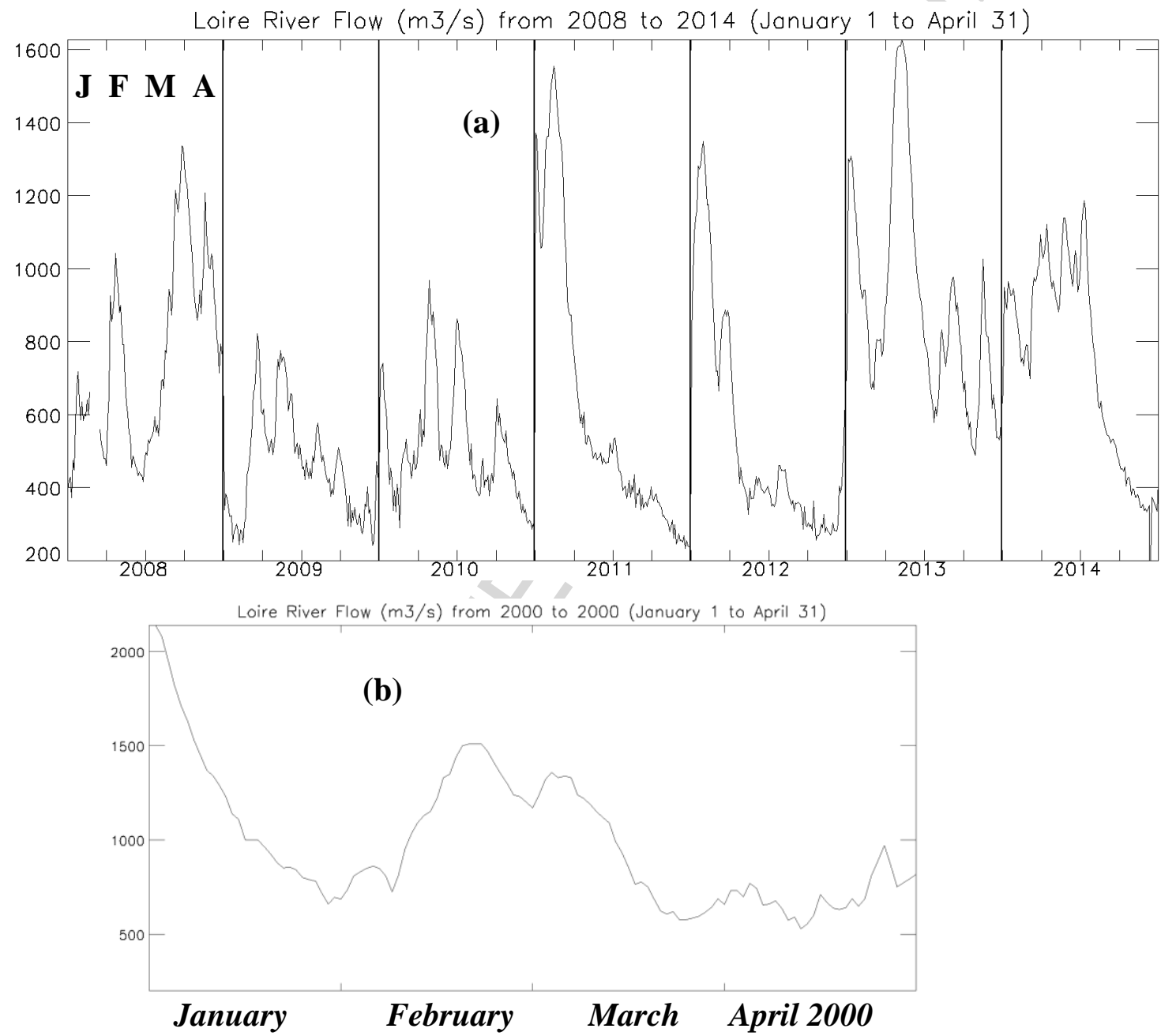

Fig. 11. Runoffs of the Loire River from January to April. (a) 2008-2014; (b) 2000

Winter 2008 appears different from other years, with late storms occurring until the end of March, clearly delaying the initiation of the blooms at our stations. Increased SPM content in the surface waters (Fig. 9), lower surface solar irradiance (Fig. 13) and higher turbulence hampered the initiation of early stratification during storms, delaying the onset of the blooms to April (Eastern Channel point) and later (other stations). 

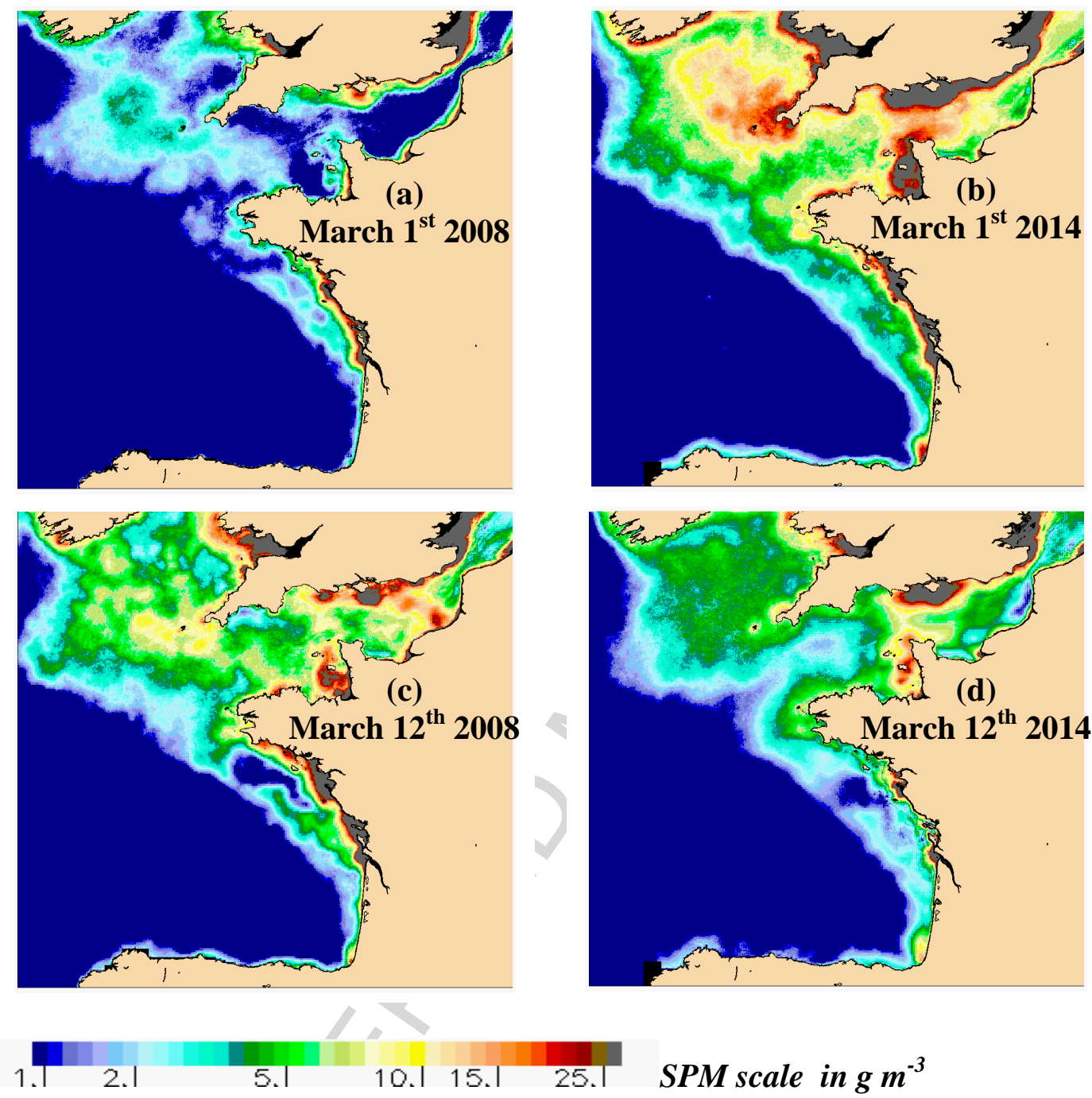

Fig. 12. Variability in the non-algal SPM at the beginning of March 2008 and 2014. (a) March $1^{\text {st }}$ 2008; (b) March $1^{\text {st } 2014 ;}$; (c) March 12 ${ }^{\text {th }}$ 2008; (d) March $12^{\text {th }} 2014$. 


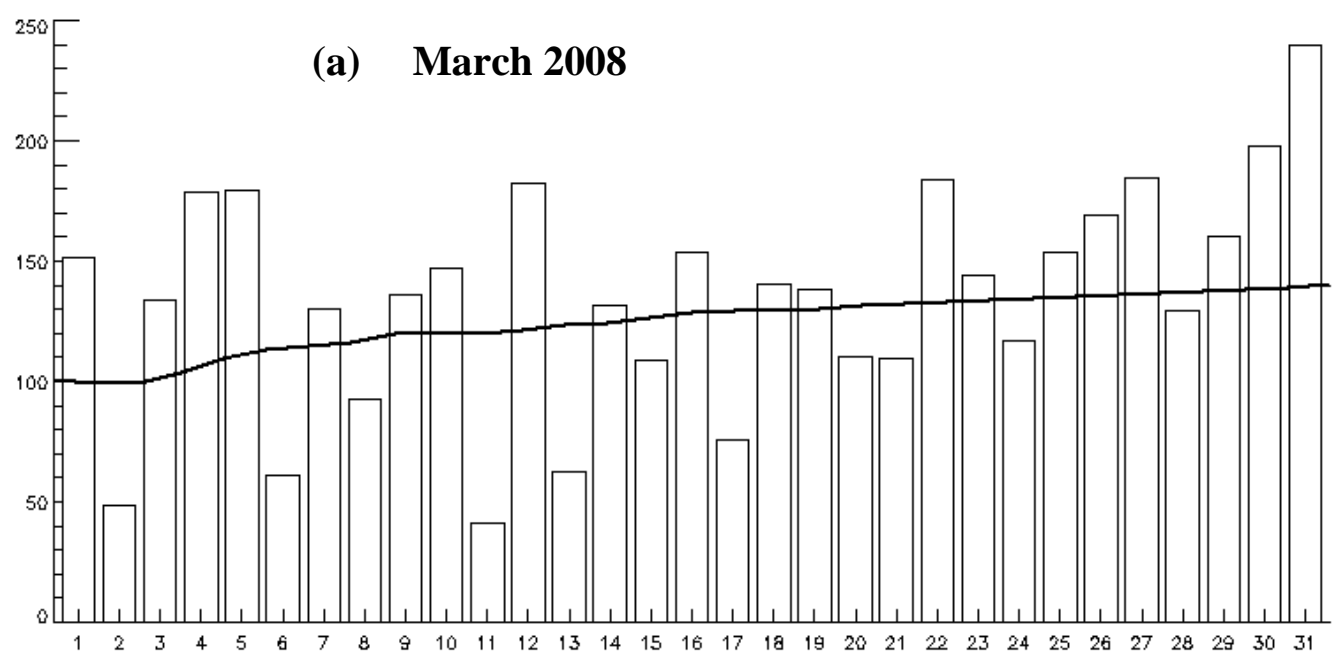

March 2008

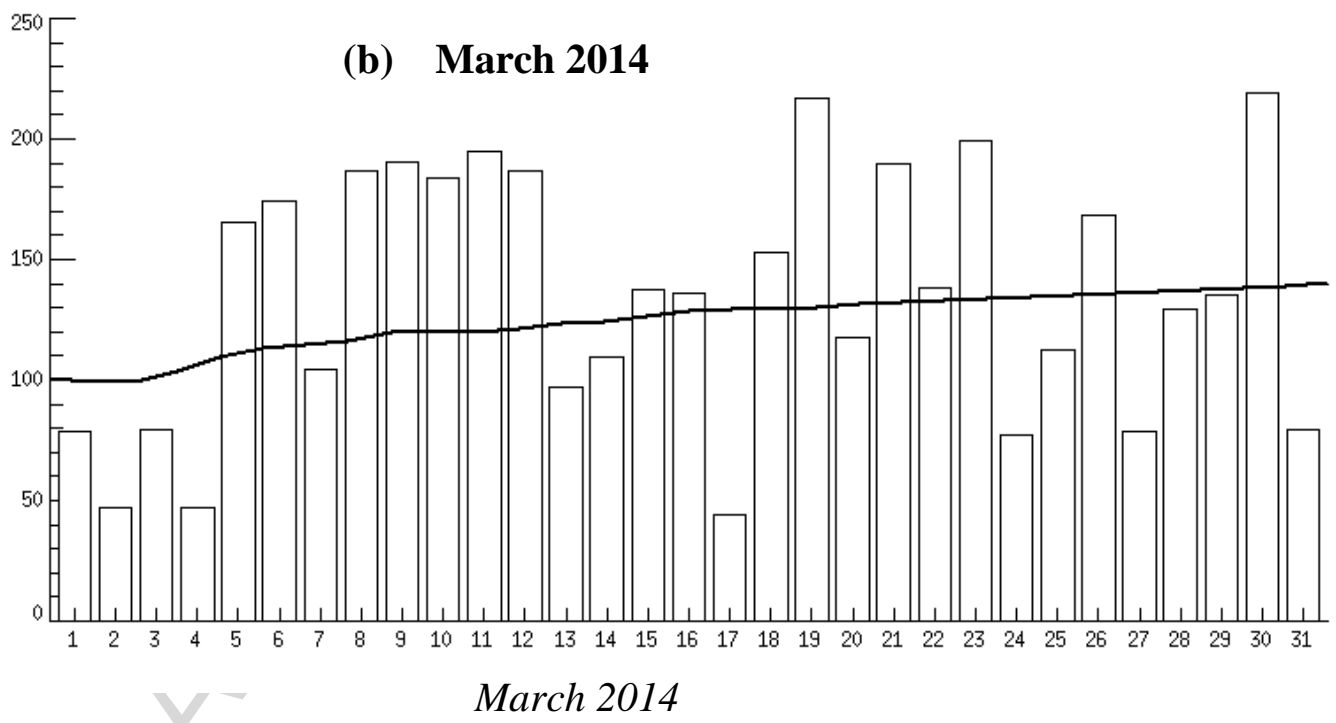

Fig. 13. Mean daily surface solar irradiance in $\mathrm{W} \mathrm{m}^{-2}$ at the southern Brittany station for March 2008 (a) and March 2013 (b) compared to the averaged irradiance over the 19982014 period (continuous lines)

From these observations we may make the following comments on the regional development of the phytoplankton blooms at the end of winter: 
Celtic Sea station: The blooms generally occur in April, however when the SPM content is too high or solar irradiance is too low, they may be delayed to the beginning of May (as in 2008).

Southern Brittany station: The continental shelf of the Bay of Biscay is heavily influenced by the river discharge from the Loire and Gironde rivers, where there are early blooms (Labry et al., 2001) within the river plumes, from the start of February but not always observed from space. The largest winter blooms, highly visible from space, occur mid-March, depending on the solar flux at the surface of the sea. When all the necessary conditions are gathered (low SPM concentration, high solar irradiance during four of five days in a row), the strongest blooms (intensity, area) are observed after rainy winters, like 2000, 2013 and 2014 in our 1998-2014 period. Fig. 5d shows that there is a large area in Southern Brittany where SPM is poorly related to waves (low coefficients $\beta$ applied to waves, in dark blue on Fig. 5d). The initiation of the blooms can begin in this area five or six days after a storm when the solar irradiance is sufficient, as in 2014.

Northern Brittany Station: In these well-mixed waters, strong blooms with high chlorophyll levels never occur, whatever the meteorological conditions.

Coastal Eastern Channel Station: As observed on Fig. 3a, there is very early development of the blooms in these shallow waters. From as soon as February, phytoplankton develops at an exponential rate. Fed by a regular import of fresh waters and nutrients from the river Seine and other coastal rivers converging into a current named "fleuve côtier" (Hoch and Garreau, 1998; Brylinski et al., 1996), the blooms develop as a function of the light, sometimes over a long period, usually several weeks when these conditions occur in February and March. This area is sensitive to storms, through their impact on water clarity and on solar irradiance at the sea surface.

In the eastern English Channel, the relationship between waves and turbidity is more complex than in the Celtic Sea or off Southern Brittany and it is not observed in the determination coefficient map of our statistical model shown on Fig. 5b. However, there is a significant effect of SPM on the timing of the bloom, as observed in 2008, 2009 and 2014 on Fig. 9d. 
Conversely to the Bay of Biscay, the storms have a greater impact on the starting of the bloom in the English Channel. In these waters, the tidal currents contribute significantly, in synergy with storms, in the stirring of the water column. The effect of advection of SPM (not directly taken into account by our simple statistical model) is also more important, with an overall eastwards flux through the English Channel.

The overall comments that we made from the time series of observations at our four sites have been extended to areas that could be defined more objectively from the time series of the daily interpolated L4 images of chlorophyll-a. Maps of bloom timing and magnitude, together with trends, have been proposed by Land et al. (2014) for the Northern Atlantic. An area of reduced magnitude of first blooms is observed in the eastern Atlantic provinces located from $37^{\circ}$ to $50^{\circ} \mathrm{N}$ and $15^{\circ}$ to $40^{\circ} \mathrm{W}$, west of the North-East Atlantic shelves provinces of our study area. Vantrepotte and Mélin (2009) assessed also a negative trend in Chlorophyll concentration in these provinces during the 1997-2008 period. Indicators such as the timing and the magnitude of the blooms (Platt and Sathyendranath, 2008), are statistically superior if carried out in well delineated provinces. Without discussing in detail the characterisation of our four stations, we may point out the Southern Brittany station which was certainly less characteristic of its province; which we can define as the distal plumes of the Loire and Gironde rivers (Gohin et al., 2003). The hydrological conditions at this place, favourable to the onset of late winter blooms are subtle, as the inner part of the river plumes is too turbid for the early initiation of significant blooms, contrary to the distal part (Gohin et al., 2003). That is also the reason why the Chlorophyll curve of the southern Brittany site, shown on Fig. 9b, had to be completed by the maps presented on Fig. 10 for a better interpretation. Significant blooms in late winter are not observed from space every year. It is only in spring (generally in May), when the solar irradiance is sufficient, that strong blooms regularly occur in the turbid plumes of the Loire and Gironde rivers. Moreover, the late winter blooms are not observed every year. Despite the complexity of the environment of our study area, this work gives the bases for a determination of homogeneous ecological provinces based on the dynamics of the SPM/Chlorophyll pair.

\section{Conclusions}


The results indicate that the high level in satellite-derived SPM observed in 2013-2014, in full consistency with waves heights, had no effect on the Celtic Sea bloom (occurring later in April) and at our Northern Brittany station. A delay and a lower growth pace were observed at our Eastern Brittany site. On the contrary, an early bloom was observed in mid-March 2014 in Southern Brittany. In March 2008, a late increase in SPM maintained a high SPM level for a longer period, delaying significantly the onset of the blooms; this 2008 event in the English Channel stimulated our interest for generating satellite-derived SPM products in spring.

Putting waves in the processing of marine reflectance allows us to improve the use of ocean colour data in phase with progress in operational coastal oceanography. Considering the processing of marine reflectance, we know that wave-generated turbulence can break up aggregations of cohesive sediments, flocs, into smaller elements (Safak et al., 2013). Within a shelf sea region this wave-generated turbulence can cause floc breakdown and turbulence-limited floc size (Hill et al., 2001; Braithwaite et al., 2012). As floc size influences the scattering of light by particles, this is a key concern within remote sensing of marine particulates, due to the direct link between particle scattering and reflectance as viewed by a satellite (Neukermans et al., 2012a; Bowers et al., 2009)

This new approach making use of wave heights and tidal intensity (spring-neap cycle) for analysing the underlying forces responsible for surface SPM, could have a natural extension in introducing the semi-diurnal tidal cycle. To this purpose, SEVIRI aboard the geostationary satellite MSG/EUMETSAT, could provide complementary information at a better temporal resolution (Neukermans et al., 2012b).

The second issue approached by this study concerns the surveillance of our coastal environment at short and long term. Based on four stations, we have been able to investigate a 17-year time period, starting with SeaWiFS data in 1998 and completed with merged products of MODIS, MERIS and VIIRS until April 2014. This study highlights the need to include the temporal variability of coupled SPM/chlorophyll for delineating ecological sub-provinces on the Northeast Atlantic shelf. Therefore, we could consider delineation based firstly on the winter/spring characteristics and secondly, on the river plumes extension in summer, particularly for addressing the risk of eutrophication in the Bay of Biscay. This task could be achieved by using remote-sensing data and in-situ measurements from conventional coastal networks. Both types of 
data have proven to be in good agreement for the surveillance of the water quality with the current generation of optical sensors, even in the coastal waters concerned by this study (Gohin at al., 2008; Novoa et al., 2012).

The identification of homogeneous sub-provinces, or water bodies, would help monitoring these regional seas, particularly in the frame of the European Marine Strategy Directive, but also in the context of climate change. However it is difficult at this stage to know from climate change projections if the windy period would extend to spring in the future.

The different analysed SPM products proposed in this study can be considered as prototypes aiming at improving the combined analysis of several parameters provided by modelling or observing centres, like those included in the MyOcean/Copernicus European project (http://www.myocean.eu).

We can also consider the use of these products in a more holistic approach and think of them at an upper level. They not only bring information on the variability of the phytoplankton environment but also on the impact of the waves on the seabed. The benthic community in fact probably being impacted more than phytoplankton by the run of storms during the winter 20132014.

\section{Acknowledgements}

The authors thank the SeaWiFS Project (Code 970.2) at the Goddard Space Flight Center, Greenbelt, MD 20771, USA, for the production and distribution of SeaWiFS and MODIS data and ESA for providing MERIS L2 data. They also thank the OSI -SAF (Ocean and Sea-Ice Satellite Application Facility) of EUMETSAT for providing daily satellite-derived Surface Solar Irradiance products. This work is a contribution to MCGS (Marine Collaborative Ground Segment) aiming at providing new tools for processing Ocean Colour data, particularly OLCI aboard Sentinel-3. It is also part of the Ifremer contribution to the MyOcean Ocean Colour TAC (Thematic Assembly Center) for defining new satellite products relevant in coastal areas. Thanks also to F. Ardhuin for providing the significant wave heights. The river discharge data were provided by Previmer, the French pilot project of Operational Coastal Oceanography. 


\section{References}

Ardhuin, F., Marié, L., Rascle, N., Forget, P., Roland, A., 2009. Observation and estimation of Lagrangian, Stokes and Eulerian currents induced by wind and waves at the sea surface, 2009. J. Phys. Oceanogr., 39, 11, 2820-2838.

Behrenfeld, M. J., Boss, E. S., 2014. Resurrecting the Ecological Underpinnings of Ocean Plankton Blooms. Annu. Rev. Mar. Sci., 6:167-94.

Bowers, D.G., Braithwaite, K.M., Nimmo-Smith, W.A.M., Graham, G.W., 2009. Light scattering by particles suspended in the sea: The role of particle size and density. Continental Shelf Research, 29, 14, 1748-1755.

Braithwaite, K.M., Bowers, D.G., Nimmo-Smith, W.A.M., Graham, G.W., 2012. Controls on floc growth in an energetic tidal channel. Journal of Geophysical Research: Oceans, 117, C02024.

Brylinski, J.M., Brunet, C., Bentley, D., Thoumelin, G., Hilde, D., 1996. Hydrography and Phytoplankton Biomass in the Eastern English Channel in Spring 1992, Estuarine, Coastal and Shelf Science, Volume 43, Issue 4, 507-519.

Capuzzo, E., Painting, S. J., Forster, R. M., Greenwood, N., Stephens, D. T., Mikkelsen, O. A., 2013. Variability in the sub-surface light climate at ecohydrodynamically distinct sites in the North Sea. Biogeochemistry 113:1-3, 85-103.

Cayocca, F., Verney, R., Petton, S., Caillaud, M., Dussauze, M., Dumas, F., Le Roux, J.F., Pineau-Guillou, L., Le Hir, P., 2014. Development and validation of a sediment dynamics model within a coastal operational oceanographic system. Mercator Ocean - Quaterly Newsletter, (49), 76-86. 
EUMETSAT, 2013. Geostationary Radiative Flux Product User Manual, version 1.3, April 2013, www.osi-saf.org/index.php

Fettweis, M., Monbaliu, J., Nechad, B., Baeye, M., Van den Eynde, D., 2012. Weather and climate related spatial variability of high turbidity areas in the North Sea and the English Channel. Methods in Oceanography 3-4, 25-29.

Filipot, J.-F., Ardhuin, F., 2012. A unified spectral parameterization for wave breaking: From the deep ocean to the surf zone. J. Geophys. Res., 117.

Garcia-Soto, C., Pingree, R.D., 2009. Spring and summer blooms of phytoplankton (SeaWiFS/MODIS) along a ferry line in the Bay of Biscay and western English Channel. Continental Shelf Research, 29, 1111-1122.

Gohin, F., Druon, J. N., Lampert, L., 2002. A five channel chlorophyll concentration algorithm applied to SeaWiFS data processed by Seadas in coastal waters, International Journal of Remote Sensing, 23, 1639-1661.

Gohin, F., Lampert, L., Guillaud, J.F., Herbland A, Nezan, E., 2003. Satellite and in situ observations of a late winter phytoplankton bloom, in the northern Bay of Biscay. Continental Shelf Research, 23(11-13), 1117-1141.

Gohin, F., Loyer, S., Lunven, M., Labry, C., Froidefond, J. M., Delmas, D., Huret, M., Herbland, A., 2005. Satellite-derived parameters for biological modelling in coastal waters: Illustration over the eastern continental shelf of the Bay of Biscay, Remote Sensing of Environment, 95, 29-46.

Gohin, F., Saulquin, B., Oger-Jeanneret, H., Lozac'h, L., Lampert, L., Lefebvre, A., Riou, P., Bruchon, F., 2008. Towards a better assessment of the ecological status of coastal waters using satellite-derived chlorophyll-a concentrations, Remote Sensing of Environment, 112, 3329-3340, 10.1016/j.rse.2008.02.014..

Gohin, F., 2011. Annual cycles of chlorophyll-a, non-algal suspended particulate matter, and turbidity observed from space and in-situ in coastal waters, Ocean Sci., 7, 705-732. 
Gohin, F., Bryère, P., Perrot, L., 2014. A new procedure for interpolating satellite-derived Suspended Particulate Matters within the Previmer context. Mercator Newsletter - quaterly Newsletter, 49, 26-28.

Hill, P.S., Voulgaris. G., Trowbridge, J.H., 2001. Controls on floc size in a continental shelf bottom boundary layer. Journal of Geophysical Research, 106, C5, 9543-9549.

Hoch, T., Garreau, P., 1998. Phytoplankton dynamics in the English Channel: a simplified threedimensional approach, Journal of Marine Systems, Volume 16, Issues 1-2, Pages 13-150.

Hurrell, James \& National Center for Atmospheric Research Staff (Eds). Last modified 20 Jun 2014. "The Climate Data Guide: Hurrell North Atlantic Oscillation (NAO) Index (stationbased)." Retrieved from https://climatedataguide.ucar.edu/climate-data/hurrell-north-atlanticoscillation-nao-index-station-based.

Klein, C., Claquin, P., Pannard, A., Napoléon, C., Le Roy, B., Veron, B., 2011. Dynamics of soluble Extracellular Polymeric Substances (S-EPS) and of Transparent Exopolymer Particles (TEP) pools in coastal ecosystems. Marine Ecology Progress Series, 427, $13-27$.

Labry, C., Herband, A., Delmas, D., Laborde, P., Lazure, P., Froidefond, J.M., Jegou, A.M., Sautour, B., 2001. Initiation of winter phytoplankton blooms within the Gironde Plume waters in the Bay of Biscay, Marine Ecology Progress Series, 212: 117-130.

Land, P.E., Shutler, J.D., Platt, T., Racault, M.F. 2014. A novel method to retrieve oceanic phytoplankton phenology from satellite data in the presence of data gaps. Ecological Indicators, 37 (PART A), 67-80.

Le Borgne, P., Legendre, G., Marsouin, A., 2006. Validation of the OSI SAF radiative fluxes. Proceedings of the 2006 EUMETSAT Meteorological Satellite Conference, Helsinki, Finland, 12-16 June 2006. Available at:

http://www.eumetsat.int/website/home/News/ConferencesandEvents/DAT_2043223.html

Ménésguen, A., Gohin, F., 2006. Observation and modelling of natural retention structures in the English Channel. Journal of Marine Systems, 63(3-4), 244-256. 
Morozov, E., Pozdnyakov, D., Smyth, T., Sychev, V., Grassl, H., 2013. Space-borne study of seasonal, multi-year, and decadal phytoplankton dynamics in the Bay of Biscay, International Journal of Remote Sensing, 34(4), 1297-1331.

Neukermans, G., Loisel, H., Mériaux, X., Astoreca, R., McKee, D., 2012a. In situ variability of mass-specific beam attenuation and backscattering of marine particles with respect to particle size, density, and compositon. Limnology and Oceanography, 57(1), 124-144.

Neukermans, G., Ruddick K., Greenwood N., 2012b. Diurnal variability of turbidity and light attenuation in the southern North Sea from the SEVIRI geostationary sensor. Rem Sens Env, 124 , p. $564-580$.

Novoa, S., Chust, G., Sagarminaga, Y. et al., 2012. Water quality assessment using satellitederived chlorophyll-a within the European directives, in the southeastern Bay of Biscay. Marine Pollution Bulletin. 64: 739-750.

Pingree, R.D., 1980. Physical oceanography of the Celtic Sea and the English Channel. In: Banner F. T., Collins B., Massie K. S., editors. The Northwest European Shelf Seas: The Seabed and the Sea in Motion. Amsterdam: Elsevier;. 638pp.

Platt, T., Sathyendranath, S., 2008. Ecological indicators for the pelagic zone of the ocean from remote sensing. Remote Sensing of Environment, 112, 3426-3436

Rees, A.P, Joint, I.R., Donald, K.M., 1999. Early spring bloom phytoplankton-nutrient dynamics at the Celtic Sea Shelf Edge. Deep Sea Research Part I: Oceanographic Research Papers, 46 (3). $483-510$.

Rivier, A., Gohin, F., Bryère, P., Petus, C., Guillou, N., Chapalain, G., 2012. Observed vs. predicted variability in non-algal suspended particulate matter concentration in the English Channel in relation to tides and waves. Geo-Marine Letters, 32, 2, 139-151. 
Safak, I., Allison, M.A., Sheremet, A., 2013. Floc variability under changing turbulent stresses and sediment availability on a wave energetic muddy shelf. Continental Shelf Research, 53, 110.

Saulquin, B., Gohin, F., Garrello, R., 2011. Regional objective analysis for merging highresolution meris, modis/aqua, and seawifs chlorophyll-a data from 1998 to 2008 on the european atlantic shelf, Ieee Transactions on Geoscience and Remote Sensing, 49, 143-154.

Sharples, J., Holt, J., Dye, S.R., 2013. Impacts of climate change on shelf sea stratification, MCCIP Science Review 2013, 67-70.

Shutler, J; Grant, MG; Miller, PI; Rushton, E; Anderson, K., 2010. Coccolithophore bloom detection in the north east Atlantic using SeaWiFS: Algorithm description, application and sensitivity analysis. Remote Sensing of Environment, 114 (5), 1008-1016.

Slingo, J., Belcher, S., Scaife, A., McCarthy, M., Saulter, A., McBeath, K., Jenkins, A., Huntingford, C., Marsh, T., Hannaford, J., Parry, S., 2014. The recent storms and floods in the UK. Exeter, UK Met Office, 27pp.

Smyth T.J., Allen I., Atkinson A, Bruun J.T., Harmer R.A., Pingree, R.D., Widdkombe C.E., Somerfield, P.J., 2014. Ocean Net Heat Flux Influences Seasonal to Interannual Patterns of Plankton Abundance. PLoS ONE 9(6).

Sykes, P. A., Barciela, R.M., 2012. Assessment and development of a sediment model within an operational system. J. Geophys. Res., 117, C04036.

Wang, X.L., Feng, Y., Compo, G., Swail, V., Zwiers, F., Allan, R, Sardeshmukh, P., 2012. Trends and low frequency variability of extra-tropical cyclone activity in the ensemble of twentieth century reanalysis. Clim Dyn 40(11-12), 2775-2800.

Vantrepotte, V., Mélin, F., 2009. Temporal variability of 10-year global SeaWiFS time-series of phytoplankton chlorophyll a concentration. ICES Journal of MarineScience: Journal du Conseil $66,1547-1556$. 
Winder, M., Sommer, U., 2012. Phytoplankton response to a changing climate. Invited review for Hydrobiologia, 698, 5-16. 